Please do not remove this page

RMIT

UNIVERSITY

\title{
Australia: Institutional changes and workforce fragmentation
}

Campbell, lain

https://researchrepository.rmit.edu.au/esploro/outputs/9921861974901341/filesAndLinks?institution=61RMIT_INST\&index=null

Campbell, I. (2008). Australia: Institutional changes and workforce fragmentation. In Globalization, Flexibilization and Working Conditions in Asia and the Pacific (pp. 115-152). Woodhead Publishers.

https://researchrepository.rmit.edu.au/discovery/fulldisplay/alma9921861974901341/61RMIT_INST:Resea rchRepository

Document Version: Accepted Manuscript 


\section{CHAPTER 4}

\section{Australia: \\ Institutional changes and workforce fragmentation}

Iain Campbell

\section{[A]1. Introduction}

Australia is undergoing a slow but significant change in employment conditions. For much of the twentieth century, the employment system, anchored in a broader "labourist/protectionist” regime that depended on tariff protection and significant state involvement in the economy (Lloyd, 2002), was stable and prosperous. At the level of labour regulation, the employment system was characterized by strong minimum standards and "fairness", supported by a generous social security system (Castles, 1985). It sustained a solid base of what, according to the standards of the time, were "good” jobs with high wages and a high standard of living for employees (and their households and communities). Labour regulation protecting employees was relatively comprehensive and relatively egalitarian, though with several gaps that allowed discriminatory treatment of indigenous workers and women. The employment system most closely resembled a European-style social democracy, though with distinct features as a result of the specific position of Australia in the global economy and the specific history of its labour-market institutions.

This system is being transformed. The change is accompanied by an intensification of inequalities within the workforce across several major dimensions of employment. This seems to go beyond a simple diversification of employment opportunities in response to the needs of a modern, diversified workforce. Instead, it is linked to what has been usefully termed a fragmentation of the workforce and the emergence of jobs that fall below the inherited norms of decent work (Watson et al., 2003).

The roots of this process go back more than two decades. In the most recent period, especially as the effects of the 1991 to 1992 recession have dissipated, the process of 
fragmentation has been overshadowed by the general conditions of economic stability and employment growth. Many individuals have enjoyed increased real wages (and ready access to credit). But quite apart from concerns about whether this stability and growth is sustainable and whether it is adequate from the broader perspective of job quality and quality of life, scholars suggest that some workers are missing out on the benefits of employment growth and even those workers that appear to be benefiting through increased wages are losing out in other respects (Borland, Gregory and Sheehan, 2001; Watson et al., 2003).

This chapter examines the change in employment conditions in Australia. Section 2 summarizes some of the driving forces behind change, such as globalization and changing public policy. In particular, it looks at modifications to labour regulation, including the radical changes that are flowing from federal legislation that came into effect in late March 2006 ("Work Choices”). Section 3 outlines the labour-market context in the most recent period, characterized by strong employment growth and low unemployment. It then goes on to examine the record of change for individual workers in selected dimensions of working conditions, drawing mainly on secondary data developed in conjunction with the monthly Labour Force Survey by the Australian Bureau of Statistics (ABS). This section focuses on the divisions separating standard employment, understood here as full-time waged work under a permanent (or continuing) contract of employment, and the varied types of nonstandard employment, such as self-employment and temporary waged work. It is argued that fragmentation, and the associated emergence of poor quality jobs, has proceeded in two main ways: first, through an expansion of non-standard types of employment, marked by inferior employment conditions and, second, more recently, through a redefinition and reduction of employment conditions within specific categories of employment, including in particular standard employment itself. Section 4 touches on selected policy debates, including on productivity growth and skill shortages. The chapter concludes (section 5 ) by examining alternative policy paths proposed in the current debates.

\section{[A]2. Globalization and labour market reforms in Australia}

\section{[B]Changing public policy}


Governments in Australia, primarily at federal level but also sometimes state governments, have sought to respond to changing economic conditions and globalization. The main emphasis has been on integrating Australia more firmly into world markets. Initiatives to support free trade, wind down tariff protection and remove financial controls have unfolded steadily since the early 1980s, initially under the federal Labor government (1983-1996) and then under the federal Liberal/National Coalition government (1996-2007). These initiatives have been supplemented by a vigorous programme of privatization. Neoliberal ideas of a withdrawal of state involvement in the economy and an enhancement of market forces, conceptualised as “deregulation”, have been influential on governments from both sides of politics (Bell, 1997).

Responsibility for labour regulation is shared between federal and state governments (Creighton and Stewart, 2005). Though federal involvement is limited under the Constitution, it quickly became the main source of innovation in this field, and since the late 1980s it has been the main site for a process of "labour market deregulation", aimed at paring back the protective elements of formal labour regulation. The process has been slow, but it has centred on dismantling the rather distinctive system of awards that was developed in the early 1900s and has been fundamental to labour regulation in Australia for most of the following 100 years (Campbell and Brosnan, 1999). ${ }^{1}$

An award can be defined as "a legal document setting out the minimum rates of pay and conditions of employment which apply to employees in a particular industry or occupation”. Awards were legally binding documents set down by permanent, independent quasi-judicial tribunals operating with powers of compulsory conciliation and arbitration. Award regulation could apply at both federal and state levels, although the former was most important and largely set the pace for the state tribunals. At the federal level the tribunal has been known as the Australian Industrial Relations Commission (AIRC). Award regulation extended throughout the economy, according to

\footnotetext{
${ }^{1}$ The following discussion is confined to federal rather than state level. Moreover, it focuses on the central labour-market institution, the (federal) award system, rather than other labourmarket institutions or, more broadly, taxation and social security policies.
} 
the coverage of the tribunal decisions, which could be occupationally, industrially, enterprise- or even nationally (through National Wage Cases) based. Individual awards numbered in the hundreds and formed a complex patchwork, which regulated the employment conditions of most - though by no means all - employees in Australia. A particular workplace could be governed by a multiplicity of awards. Individual awards were interlinked by common principles and attention to the preservation of pay relativities (under the principle of “comparative wage justice”). Each award typically contained a multitude of provisions, extending beyond basic employment issues to cover matters that in other countries might be regulated through statute or the social welfare system. By contrast, statutory regulation in Australia played only a limited role. It was largely confined to legislation at state level and to a few matters such as public holidays, minimum standards of annual or long service leave, occupational health and safety, and workers' compensation. Finally, underpinning award and statutory regulation was the primitive form of regulation provided by the common law (Creighton and Stewart, 2005).

The award system is best understood as the somewhat messy way in which Australian society provided for the dynamic labour standards that could ensure a platform of “decent” work (Cooney, Howe and Murray, 2006). Though it had a distinctly statist form, it operated in ways that are similar to conventional systems that mix together statutory regulation and collective bargaining. Indeed the award system is best seen as a collective bargaining system (Clegg, 1976; Traxler, Blaschke and Kittel, 2001). At the same time, this system was complicated and layered - it was fragmented. Partly as a result, it was also rather porous, leaving sizeable gaps as a result of poor coverage, poor enforcement and numerous exemptions. Table 4.1 provides ABS data from an employer survey conducted in 1990. It shows a reasonably comprehensive coverage of employees of around 80 per cent. But this still left a large gap. The remaining 20 per cent of employees was protected only by the rudimentary provisions offered by statutory regulation and by the common law individual contracts of employment. This group included most managerial and executive employees, but it also included a substantial number of non-managerial employees who seemed to be located 
predominantly in small private sector workplaces and predominantly at the bottom of the income and occupational hierarchy. ${ }^{2}$

\section{TABLE 4.1 ABOUT HERE}

Was the award system too rigid? Certainly it was deficient in several ways. The fact that it was complicated and layered made it opaque (Campbell and Brosnan, 1999). The fact that one workplace could be governed by several awards (as well as other regulatory instruments) often offered a formidable challenge to the understanding of managers, employee representatives and shop-floor workers. Certainly the award system constrained the choices of employers, but it did not neglect their interests; thus, it allowed for different forms of flexibility to respond to business needs, such as shift work and overtime, and it left substantial room for enterprise-level bargaining and arrangements. From one point of view, its central deficiency was precisely that it was too flexible. Thus the many gaps in the system allowed too many opportunities for favourably situated firms to avoid protective regulation. This fostered unfair advantages for certain firms and amplified pressures on the remaining firms, often larger and more open to public scrutiny, that complied with labour standards. The calls from large firms for "labour-market deregulation" in the 1980s can be seen as aimed at equalizing these advantages - a demand that what could be called implicit deregulation should be matched by explicit deregulation.

The award system was ramshackle and undoubtedly required modernization. It needed to be adapted to new occupations and industries, changing workforce composition and new worker needs. However, apart from a burst of "award restructuring” in the late 1980s, public policy has aimed not so much at modernization as at abolition. The dismantling proceeded in a series of steps. At the crucial federal level, it started with the federal Labor government in the early 1990s and then continued more enthusiastically and with more emphasis on restriction of trade unions

\footnotetext{
${ }^{2}$ As Table 4.1 indicates, the sectoral dimension is very important. The proportion of employees outside coverage in the public sector was minimal (2.2 per cent), but it was more substantial (27.6 per cent) in the private sector. As could be expected, there was also a major difference according to size in the private sector, with large enterprises (or "employer units") more likely to have the bulk of their employees covered, but many small enterprises reporting that their employees were not covered (ABS, 1990).
} 
under the subsequent Liberal/National Party Coalition government. The latest step, referred to here as "Work Choices", 3 was taken by the federal Coalition government after their fourth election victory in October 2004, when they finally won control of both Houses of Parliament and could more easily implement their policies. This radical legislation sparked fierce debate about the future of existing labour standards and working conditions in Australia, and it proved to be a major issue in the November 2007 election, when the Coalition was replaced by a new Labor government. The incoming government has promised to introduce legislation in 2008 to remove 'Work Choices', but as yet it remains unclear what the legislation will contain and how different the new system will be.

\section{[B]Dismantling of the award system}

Roughly summarized, the dismantling of the award system targets two crucial elements: coverage and the substantive content of labour standards. ${ }^{4}$

\section{[C]Coverage}

The formal changes since 1990 preserve awards (though these have lost most of their broad social functions and have become increasingly residual). But they add on at least three further streams of regulation: (a) (registered) single-employer agreements with unions; (b) (registered) single-employer agreements with a group of workers organized outside of unions; and (c) registered individual contracts. These additional regulatory streams are oriented to individual enterprises, and they have introduced a significant element of decentralization - as well as a significant element of enhanced employer power - into the regulatory system. The Labor government sponsored the addition of the first two streams, arguing that they represented a new system of “enterprise bargaining” to supplement the traditional awards. The Coalition government, in its initial Workplace Relations and Other Legislation Amendment Act

\footnotetext{
${ }^{3}$ We refer loosely to the entire bundle of changes as "Work Choices". The main piece of legislation is based on an amendment to the existing Workplace Relations Act, entitled the Workplace Relations Amendment (Work Choices) Act 2005. However, the regulations that accompany the legislation, as well as other pieces of legislation dealing with issues such as independent contractors and the building and construction industry, are also important. ${ }^{4}$ Another crucial element is its negative impacts on worker representation and collective bargaining. This issue is not discussed in this chapter for the reason of space limitation.
} 
1996, revised and strengthened the provisions for non-union agreements and introduced the third stream of registered individual contracts, entitled Australian Workplace Agreements (AWAs). The 2005 Work Choices legislation consolidates this framework, seeking to expand the favoured stream of registered individual agreements. In addition, it uses the corporations' power in the Constitution to expand the federal system at the expense of the state systems. This extends the reach of the federal system to around 80 per cent of all employees and displaces some of the more generous provisions and procedures available through state awards and agreements and through state legislation.

Registered agreements could be concluded by trade unions, but they could also be concluded by individual employers working either with a group of employees or with employees singly. Agreements are often described as the result of "bargaining”, but there is little sign of any bargaining with either non-union agreements or AWAs. The latter are generally template agreements offered to individual employees to sign, and indeed current jurisprudence ratifies the practice of offering new employees an AWA as a condition of being employed (Mitchell et al., 2005). The most recent legislation further relaxes the requirements regarding procedures for reaching agreement. The “collective agreements”, which included both union and non-union agreements, were traditionally registered with the AIRC, but a new body, the Office of the Employment Advocate (OEA), was established after 1996 to register AWAs and this body has now been given the responsibility for filing all agreements.

The present distribution of workers among the different streams of regulation is difficult to calculate, because of the possibility for workers to be in several streams at once, for example with part of their pay and conditions regulated by awards and part regulated by some other form of agreement. Table 4.2 offers some hints. It suggests that the proportion of employees paid exactly the award rate in 2006 was relatively small - 19 per cent. ${ }^{5}$ What were the main alternatives to awards? The category of registered individual agreements (mainly federal AWAs) was of only minor

\footnotetext{
${ }^{5}$ This should not be taken as an exact reflection of the relative significance of awards. Many who had their pay set by awards plus another method would be classified to the other method. Moreover, for many employees awards can still be significant for non-monetary benefits and conditions and can still be a reference point for pay.
} 
importance (3.1 per cent). One large category was unregistered individual agreements, which covered 31.7 per cent of employees, but this is likely to be a heterogeneous group, made up of some employees in an unregulated sphere, governed primarily by common law individual contracts, together with some employees whose pay is primarily set by award or agreement but who enjoy an extra (“over-award”) payment granted by their employer. After that we have registered collective agreements, which account for 38.1 per cent of employees. These data do not distinguish between union and non-union registered collective agreements (but it is likely that the union agreements are far more numerous).

\section{TABLE 4.2 ABOUT HERE}

If we compare Table 4.2 with Table 4.1 we can get a rough perspective on the changes since 1990. In the public sector, there appears to have been a decisive movement of workplaces and employees into registered collective agreements. In the private sector the change appears less dramatic and is more fractured. Awards remain important, especially in industries such as hospitality and retail, which contain large numbers of female, often low-paid, workers. Where there is a passage away from awards in the private sector, it has been made up both of movement into the less regulated sphere of unregistered individual agreements and of movement into registered collective agreements.

\section{[C]Substantive content}

For those moving from awards into agreements the Labor government introduced a "No Disadvantage Test” on agreements, as a reassurance that agreements would not be used to lower wages and conditions in comparison with awards. Awards were thereby presented as a "safety net” for enterprise bargaining. The "No Disadvantage Test” contained weaknesses from the start, and it was progressively watered down by both Labor and Coalition governments. In addition, the effectiveness of awards as a safety net was undermined by changes in their mode of operation. Some of these changes were indirect, as a result of the barriers to updating award provisions and as a result of the weakening of enforcement mechanisms. However, others were more direct and served to reduce the substantive content of the labour standards in awards. 
Under the Labor government, the AIRC had been encouraged to "liberalize” clauses in awards, but the major change came in 1996 with the advent of the Coalition government, which launched a process of “award simplification”. This involved a restriction of the powers of the AIRC to 20 "allowable award matters”. Other award provisions were proscribed and were required to be removed from existing awards by June 1998 (although some could be regained through negotiation with individual employers issuing in certified agreements and AWAs).

The 2005 Work Choices legislation introduces further impediments to altering and updating awards and continues the narrowing down of "allowable matters”. However, the main effect is elsewhere. The legislation discards the "No Disadvantage Test(s)" and thereby severs the (attenuated) links that connected agreements and awards. In response to public concerns, the federal government retreated slightly in 2007 and introduced a new "Fairness Test” (Sutherland, 2007). However, the main mechanism that is intended to provide a floor or safety net under agreements is the Australian Fair Pay and Conditions Standard (AFPCS). This covers a minimum wage, paid annual leave, paid personal leave, unpaid parental leave and a maximum limit on ordinary weekly working hours. Scholars (Fenwick, 2006; Stewart, 2006; Cooney, Howe and Murray, 2006) have pointed to the limited range of these provisions. They suggest, even in these five cases, that the appearance of minimum standards is deceptive, since the provisions do not apply to all workers, and, where they do, there are ample opportunities for derogation. For example, the four-week annual leave provision does not apply to casual workers and can in any case be partly "cashed out”. Nor is there any plausible mechanism for adjustment, except in the case of minimum wages (including junior, training and disability wages, casual loadings, and pay and classification scales), which are the province of a new body, the Australian Fair Pay Commission (AFPC) (Waring, de Ruyter and Burgess, 2005).

One major initiative concerns new rules around "unfair dismissal”. Firms with fewer than 100 employees are exempt from requirements to avoid "unfair dismissal”, and firms with larger numbers are allowed to introduce new arguments such as “operational reasons” to reach the same outcome (Chapman, 2006). This undermines the employment security of large numbers of employees, who had previously enjoyed some protection from dismissal that could be judged "harsh, unjust or unreasonable". 
The initiative responds to a long-standing and fierce campaign by employer associations, who had denounced the "unfair dismissal” legislation of 1994 as an impediment to job creation, especially in small business. Yet both the campaign and the recent government initiative seem hard to justify: Australia has traditionally been near the bottom of OECD rankings in terms of the strictness of its regulations for employment protection (OECD, 2004). Furthermore, it does not seem likely, according to current research, that a weakening of these already weak provisions will stimulate any significant employment growth (Freyens and Oslington, 2005; see OECD, 2006, p. 212).

\section{[A]3. Changes in employment conditions for individual workers}

This section starts with the labour-market context, seeking to identify the extent and significance of the strong employment growth experienced in recent years. It then goes on to look at selected dimensions of working conditions: type of employment, working time, wages, gender equality and work-family balance, and health and safety, in order to throw light on the mixed record of change in employment conditions.

\section{[B]Employment and unemployment}

The paid workforce has grown strongly in recent years, rising from less than 8 million workers in the early 1990s to over 10 million workers (10,172,000) in August 2006 (ABS, 2006b). This growth has two components - an overall increase in the workingage population and a steady increase in the employment rate (also called the “employment to population ratio”).

The employment rate for working-age (15-64) persons has risen from 64.1 per cent in 1978 to 72 per cent in 2006 (see Figure 4.1). The current figure is higher than the OECD average (and higher than Japan and the Republic of Korea), but it is about the same as the United States, and it remains lower than leading nations such as the Nordic countries (OECD, 2006, p. 248). Figure 4.1 indicates that, as in other countries, the pattern of change is different for men and women. Whereas the employment rate for men only slowly recovered from the sharp decline of earlier 
years, the employment rate for working-age women shows a steadier and much stronger pattern of growth to reach a peak of 65.4 per cent in 2006 (up from 29 per cent in 1954 and 48 per cent in 1980).

\section{FIGURE 4.1 ABOUT HERE}

New patterns of participation in the workforce underpin these figures. First is the trend to increased female participation, which is common to many countries but often takes distinctive national forms. In Australia, it is an expression of the long-term transformation of the male breadwinner/female homemaker model that had been dominant in the first half of the twentieth century. This process of transformation is strong but unfinished. Thus female employment rates are still lower in all age groups than for men, and employment gaps persist, especially for women with dependent children. Moreover, female participation takes particular forms, with many women experiencing temporary periods of withdrawal from the labour force when children are young and then seeking a gradual re-entry into the workforce, often into part-time jobs. These new patterns of participation point to the increased importance of labourmarket transitions (Schmid and Gazier, 2002).

Second, youth labour markets have undergone major changes, which are only partly revealed in the changing employment rates for young people. Increased retention rates in secondary schools and the expansion of higher education have meant fewer school leavers seeking full-time work. But this does not necessarily entail a decline in employment rates for young people. More and more full-time students seek to combine their study with part-time jobs. Indeed, Australia now has come closer to the US as a country with very high rates of student employment, predominantly in parttime jobs in sectors such as retail and hospitality.

Strong employment growth has been accompanied by falls in unemployment, including long-term unemployment. After reaching 10.5 per cent of the labour force in August 1993, the official unemployment rate has declined to below 5 per cent (see Figure 4.2 below). This is relatively low in international comparison (OECD, 2006, p. 247). 
The raw figures on employment and unemployment suggest a comfortable labourmarket context. Indeed some voices speak of a return of "full employment". But to produce a more balanced assessment, it is important to go beyond such raw figures. First, we can note that the record of employment growth is less impressive when measured in volume terms rather than just in terms of head count. Much of the growth in employment has been in part-time employment, sometimes only with very short hours. Thus around 45 per cent of the total employment growth over the period 1994 to 2005 was in part-time employment (ABS, 2006a). Table 4.3 shows the increase for both men and women over this period.

\section{TABLE 4.3 ABOUT HERE}

The absolute and relative growth of part-time employment is a major feature of changing labour markets in Australia, continuing a process that stretches back to the 1950s. As can be seen, women are the major source of growth, but young workers, both female and male, have also contributed. According to the harmonized OECD data (OECD, 2006, p. 264), the percentage of the workforce that was part time in Australia in 2005 (27.3 per cent) was very high in cross-national comparison. For men the figure was 15.7 per cent, just ahead of the Netherlands at the top of the OECD rankings, while for women it was 41.7 per cent (behind the Netherlands but near the top of the rankings, together with Japan) (ibid., p. 263).

Second, as numerous scholars have noted (Watson, 2000; Denniss, 2001), official measures of unemployment are increasingly inadequate as a guide to the health of the labour market. One necessary supplement is a measure of "hidden unemployment", which takes account of persons who may wish to take a job but who are counted as not in the labour force because they fail to meet the criteria of availability and/or job search. As the employment rates indicate, there are still substantial pools of jobless persons of working age. The other necessary supplement is a measure of (timerelated) underemployment, which takes account of persons who meet the requirement for being counted as employed but who want to work more hours. This is particularly significant in Australia, linked to the prevalence of part-time jobs. Figure 4.2 charts the changes in the unemployment rate and in two versions of the underemployment rate. This shows a strong increase in underemployment, jumping from 1.9 per cent in 
1978 to 6.7 per cent in 2006. As Figure 4.2 indicates, the proportion of the labour force that is underemployed is now more than the proportion counted as unemployed. This proportion seems higher than for any other industrialized country (ILO, 2005).

\section{FIGURE 4.2 ABOUT HERE}

The ABS has developed a measure of the "extended labour force underutilization rate", which groups together "the unemployed, plus the underemployed, plus a subset of persons marginally attached to the labour force, expressed as a proportion of the labour force augmented by the marginally attached persons”. This rate declined from 15.5 per cent in September 1994 to 11.4 per cent in September 2005 (ABS, 2006c). This offers a more mixed, but more accurate picture of the health of the labour market, indicating that the improvement in labour-market conditions since 1994 was largely confined to a drop in official unemployment, with little change in the proportions of the labour force that were underemployed or marginally attached. ${ }^{6}$

A balanced assessment of employment growth also needs to incorporate a discussion of job quality. As the following sections indicate, there is ample reason to be concerned about trends in job quality.

\section{[B]Types of employment: Permanent, fixed-term, casual and part-time employment}

As in other industrialized societies, the employment system in Australia evolved around a model of standard employment, roughly defined as full-time, "permanent” waged work. Starting with employment security, enshrined in the principle of an open-ended employment contract ("permanency”), varied employment rights and benefits were consolidated and added on to the framework of standard employment over the course of the twentieth century. In this way standard employment became the

\footnotetext{
${ }^{6}$ A good measure of the health of the labour market would also need to introduce a dynamic element, which can take account of the growth of phenomena such as intermittent employment (Watson et al., 2003, pp. 34-37).
} 
platform for the achievements of the Australian system in offering good jobs and a high standard of living for the bulk of the (male) workforce. ${ }^{7}$

In addition to standard employment, the employment structure contains varied forms of non-standard employment, characterized by less protection and fewer employment rights and benefits. As in other advanced capitalist societies, the two main lines of division are: (a) the line separating employees from the self-employed; and (b) the line separating "permanent” employees from other types of employees, who can be called "temporary" (Supiot, 2001). In addition, there is a third line of division within the group of permanent employees that separates full-time workers from those working hours less than full-time. ${ }^{8}$ Most non-standard work is within a formal sector, and the informal sector is only small. However, as noted above, the labour regulation system in Australia has been porous. Self-employment has been little regulated, and coverage for employees has been less than comprehensive. Similarly, exemptions from regulation and poor enforcement can be seen to create pockets of informality even within the heart of the formal system.

These lines of division have taken distinctive forms in Australia, due to the history and distinctive institutional forms of labour regulation. The line separating employees and non-employees is largely regulated by common law, progressing by means of an accretion of court cases that seek to deploy varied tests in order to establish the difference between a contract for service and a contract of service, that is an employment contract (Bennett, 1994, pp. 171-177). The result has been confusion and extensive opportunities for employers to exploit the boundary (Creighton and Stewart 2005; Stewart 2002). This has given rise to concerns about the growth of a significant group of “dependent contractors” (also called "fake self-employed” or “disguised wage labour”), who are dependent on one employer and appear largely

\footnotetext{
${ }^{7}$ Other terms are sometimes used for full-time permanent waged work, such as "regular", "typical" or "traditional” work. I prefer the term "standard" because it gestures towards its role as a pivot of the labour regulation system. This allows recognition of the fact that the employment rights and benefits that are attached to the basic type of employment can vary, for example, over time and between different nations. This connects up with the valuable literature on the "standard employment relation" (see Bosch, 2004).

${ }^{8}$ We put aside a few minor categories of non-standard employment that also involve fewer rights and benefits and lesser protection, such as apprenticeships and traineeships and government-sponsored employment schemes. Temporary agency work is briefly discussed below.
} 
indistinguishable from employees in the way they work within the workplace, but who do not enjoy the standard rights and benefits of employees.

The line separating “permanent” employees from “temporary” employees is particularly distinctive in Australia. In comparison with other advanced capitalist countries, temporary employment is marked by more unusual forms and by a bigger gap in protection (Campbell and Burgess, 2001). The two main types of "temporary" waged work are fixed-term and casual. Fixed-term employees are familiar in international comparison. In Australia they are concentrated in the government and not-for-profit sector, especially in areas such as education and community services, and they differ from "permanent" employees in those sectors mainly in terms of their limited employment security as a result of a contract of employment that is for a specified duration (or life of project) (Watson et al., 2003).

However, the Australian category of "casual” work is more unusual. Historically, this has been the main type of employment specified in labour regulation as an alternative to the standard model of permanent employment (O'Donnell, 2004). As in most countries, it is possible to find casual workers in Australia whose poor conditions result from their shadowy presence within an informal or illegal sector. However, the majority of casual workers in Australia are fully within the mainstream of the formal, regulated sector. They are recognized as employees, but in most protective regulation - whether legislation or awards and agreements - they are governed by special clauses that permit this form of employment, under certain limitations, and then specify that these workers are exempted from most rights and entitlements, starting with employment protection (rights to notice and compensation in case of dismissal), but easily extending into most rights and entitlements, including such basic entitlements as paid annual leave. They are categorized as workers entitled to an hourly wage (sometimes with a “casual loading”) for each hour spent under the direction of the employer at the workplace, but to very little else. In short, they are regulated but not effectively protected. ${ }^{9}$ The existence of this category of workers is a

\footnotetext{
${ }^{9}$ The meaning of "casual” remains contested, and an employer designation of someone as “casual” is by no means conclusive (O’Donnell, 2004; Creighton and Stewart, 2005). If casual workers are able to prove continuity of service and regular schedules, workers may, in the eyes of the courts, acquire rudimentary rights and entitlements.
} 
surprising but crucial feature of the Australian system. It is difficult to find any other OECD country, with the exception of the US, where is legal to deprive employees of such standard leave entitlements as paid annual leave and paid public holidays (Campbell, 2004). Most casual workers are part time, but a significant and growing minority are full time. Casual work incorporates a large group of workers across all industries, but with particular concentrations in retail, accommodation, cafés and restaurants, and cultural and recreational services.

Both fixed-term and casual types of employment are described here as "temporary" because they lack the employment protection associated with standard work. However, in practice such workers can assemble long periods of tenure in the job. Thus fixed-term contracts can be rolled over repeatedly, while workers in casual jobs may slip into regular rosters and long-term relationships with the employer. Data from the first wave of the Household, Income and Labour Dynamics in Australia (HILDA) survey suggest that mean years of job tenure for "permanent" employees were 7.3, but for fixed-term employees it was 4.4 and even for casuals it was 2.6 years (Wooden and Warren, 2003, p. 13).

Table 4.4 presents information on the distribution of workers in the main types of employment in Australia from a recent survey (van Wanrooy et al., 2007; see also Louie et al., 2006). As can be seen, standard work, that is permanent full-time waged work, accounts for less than half of the workforce.

\section{TABLE 4.4 ABOUT HERE}

The standard workforce has declined in significance in recent decades. Figure 4.3 uses one measure of full-time "permanent” employees to show the change since $1984 .{ }^{10}$ The numbers rose in the employment boom of the late 1980s, but they declined sharply in the recession of the early 1990s and have only slowly recovered in the

\footnotetext{
${ }^{10}$ The measure used in Figure 4.3 has two main deficiencies. First, these data are based on a broad definition of "employee" that includes owner-managers of incorporated enterprises. Second, the definition of "permanent" relies on entitlement to either paid annual leave or paid sick leave (or both), and it thereby includes fixed-term employees. The first problem is overcome in more recent data that are cited elsewhere in this chapter. However, because the data based on the broader definition of "employee" allow a longer time series, they are used in Figures 4.3 and 4.4.
} 
period since. As a proportion of the workforce, full-time permanent employees have declined fairly steadily over the entire period from 64.4 per cent in 1984 to 52.1 per cent in 2006. The decline has been most marked for males, but it has been substantial even for females.

\section{FIGURE 4.3 ABOUT HERE}

The decline in standard employment as a share of the workforce has been matched by a rise in some, though by no means all, forms of non-standard employment. First, the proportion of non-employees in the workforce currently stands at around 20 per cent. The proportion has been stable since the early 1990s (ABS, 2006a), though within this broad category it is likely that groups such as "dependent contractors" have grown in significance.

Second, estimates of the proportion of the workforce on a fixed-term contract vary widely, with one estimate for 2004 suggesting only 3 per cent and another suggesting 6.6 per cent (see Productivity Commission, 2006, pp. 130-131; see also Watson et al., 2003, p. 64). As a result, it is hard to reach conclusions about the long-term trend of growth.

Third, the most important type of temporary work is "casual”. The best estimate suggests that "casual” employees represent around 20 per cent of the workforce (ABS, 2006a). The growth in numbers over the past few years has been moderate, but prior to that time there was a trajectory of strong growth that generated a steady increase in the proportion of the workforce classified as casual. Figure 4.4 uses one measure of "casual” employees to show the change since 1984. The proportion rose sharply from 13.1 per cent in 1984 to 22.1 per cent in 1996, with a subsequent smaller increase to 23.2 per cent in 2006.

\section{FIGURE 4.4 ABOUT HERE}

Finally, part-time employment has expanded rapidly. In 200558.6 per cent of all parttime employees were classified as "casual” and the remainder were classified as “permanent” (ABS 2006a). Both groups have grown as part-time work has increased, 
with a particularly strong increase in the permanent part-time workforce in recent years. As a result, the proportion of the workforce classified as part-time permanent has increased from 6.5 per cent in 1992 to 9.7 per cent in August 2005 (ABS, 2006a).

In sum, the share of the workforce in non-standard employment has expanded, particularly in the period prior to 2000. Casual employment is the largest category of non-standard employment; its growth made the biggest contribution to the growth of non-standard employment in the 1980s, and it has still made a substantial contribution over the period since the early 1990s. As noted above, dependent contracting is likely to have grown, but the overall numbers remain small.

The growth in both casual work and dependent contracting can be linked with a growth of temporary agency work (sometimes referred to in Australia as "labour hire”). Temporary agency work is not strictly a separate type of employment, but simply a different way of organizing the existing types of employment discussed above, based on a triangular relationship joining together the agency, a user firm and the worker (Watson et al., 2003, pp. 72-77). It is prominent in particular areas, including construction, communications and utilities, agriculture, manufacturing (food and beverages, maintenance work), nursing and clerical work. Temporary agency work is subject to limited regulation in Australia, and much detail of its operations remains obscure (Coe, Johns and Ward, 2007). However, it is clear that only a small minority of workers organized by temporary agencies are "permanent” employees. The vast majority is casual, but another small group has been recognized as selfemployed contractors, after a fiercely contested court case in the early 1990s. The best estimate of the size of the temporary agency workforce suggests that it accounts for between 2.5 and 3 per cent of total employment (Hall, 2006, p. 159; see also Laplagne, Glover and Fry, 2005), which is relatively high in international comparison. Researchers are agreed that that there was rapid growth in the 1990s (Laplagne, Glover and Fry, 2005), but there is less agreement about the recent trend, with some data pointing to stability over the period 2001 to 2004 (Productivity Commission, 2006, pp. 108, 139-140).

The decline of standard employment implies a decline of good jobs. Conversely, the rise of non-standard employment, generally characterized by limited protection and 
inferior employment rights and benefits, implies a rise of poorer quality jobs. This is sometimes discussed in terms of increased precariousness (for example, Louie et al., 2006). Each category carries its own concerns. However, we can note that that the biggest category is the Australian version of casual, and this tends to carry with it the biggest set of problems.

The expansion of these forms of non-standard work is best seen as a rather accidental process, which results from the evolution of work within an imperfect regulatory regime (Pocock, Buchanan and Campbell, 2004, p. 22). It is not, as in some European countries, a product of government decisions aimed at meeting employer demands for increased flexibility in an indirect fashion, while still preserving strong employment protection for permanent employees. Government action has been important, but it has tended to be targeted at the conditions of standard work, and it has paid less attention to the conditions associated with non-standard work.

\section{[B]Working time}

Some scholars identify working time as the major site of changed employment conditions since the mid-1980s (ACIRRT, 1999; Buchanan et al., 2006), and it is important to consider this dimension carefully. The changes incorporate some advances for employees, building on the long-term trajectory of improvement in leave entitlements and reduction in working hours. The reduced working hours campaign of the late 1970s was partially successful, leading to reductions in standard hours for many full-time employees, to 38 hours per week in most cases (generally taken in the form of rostered days off - RDOs). But since that time, signs of progress in meeting the individual or collective needs of employees have been harder to find. Campaigns have been mounted but few have met any success. For example, the 2002 effort to persuade the federal government to introduce a national scheme of paid maternity leave failed. Some limited gains in other respects have been achieved. Entitlements to unpaid leave entitlements were boosted through Test Cases before the AIRC, first with unpaid parental leave in 1990, then with the Special Family Leave Test Case in 1994, and most recently in the Family Provisions Test Case in 2004 to 2005 (Murray, 2005). Efforts by trade unions at national level to secure controls on long hours through a "Reasonable Hours Test Case" in 2001 achieved a sympathetic hearing, 
though the outcome was weak and ineffective. It is possible to point to limited advances through collective bargaining at enterprise level. For example, provisions for paid maternity leave have been introduced into some agreements, but the entitlements are generally less than the ILO standard and are concentrated among well-paid full-time women, with most women who need it continuing to miss out (Baird, 2005). A recent study, based on a 2005 survey of mothers, indicates that around 34 per cent of all mothers who were employed in the 12 months prior to the birth of their child took some paid maternity leave (for an average duration of around 11 weeks) (Whitehouse et al., 2007, pp. 107-108).

Working-time changes can be charted through the experiences of full-time and parttime workers. Among full-time employees, the most important and most suggestive change has been the lengthening of average hours, in sharp contrast both to the prior historical experience and to the contemporary trends in most other OECD countries. As Figure 4.5 shows, average actual weekly hours for full-time employees in Australia rose from 38.2 in 1982 to 41.9 in 2000, before falling back slightly to 41.2 in the latest count in 2006. Both males and females show a similar pattern of increase, though the male mean remains higher than the female mean. The main component has been an increase in the proportion of full-time employees who have been working very long hours of 50 or more per week.

\section{FIGURE 4.5 ABOUT HERE}

This experience of lengthening full-time hours is unusual, though similar trends can be noted in countries such as the US, New Zealand and the United Kingdom. The trend in Australia started from a relatively low base in the early 1980s, perhaps reflecting the legacy of a long history of achievements in reducing hours, but the current mean is high in comparison with most OECD countries, though still below the levels recorded in the Republic of Korea and Japan (Lee, 2004, pp. 41-43; Campbell, 2007). ${ }^{11}$

\footnotetext{
${ }^{11}$ Data on average annual hours for all employed persons are the usual basis for comparison, but they are distorted by virtue of the impact of part-time workers. As noted above, Australia has a very large component of part-time workers, which depresses the average compared to many other countries. Nevertheless, its annual average hours still appear quite long. In 2005
} 
Analysis suggests that the increase in full-time hours is primarily due to an increase in unpaid overtime (Wooden et al., 1994; Campbell, 2007). Both the number of employees working unpaid overtime and the volume of this overtime in Australia were already significant in the early 1990s, but they have now become more significant. Data for the proportion of full-time employees working overtime on a regular basis show an increase from 39 per cent in 1993 to 46.1 per cent in 2003, much of the rise occurring among the group of workers not directly remunerated for their overtime (Table 4.5). As Table 4.5 indicates, overtime is heaviest among permanent full-time employees, but it also affects the small group of casual full-time employees. Though concentrated among managers and professional workers, the phenomenon of unpaid overtime seems to have spread to most occupational groups, signalling a deterioration in working-time conditions.

\section{TABLE 4.5 ABOUT HERE}

The experience of lengthening hours, often in the form of unpaid overtime, can be linked with the weakness of the regulation of standard hours and overtime. Many of the crucial elements found in other regulatory systems, such as maximum daily hours, maximum weekly limits and maximum overtime limits are missing, and the limits that do exist, such as the prescription of payment or time-off-in-lieu for overtime, are undermined by the prevalence of numerous gaps (Campbell, 2007, pp. 51-57). In addition, the absence of protective conditions around the use of overtime means that extra hours at the demand of the employer are more -or less mandatory. The already weak regulation has been further weakened in the course of labour-market deregulation. The new minimum floor of conditions introduced as part of the Work Choices package introduces a provision for a "maximum” of 38 ordinary weekly hours, but this does not function as any kind of maximum because it can be averaged over a year and can be supplemented by any number of "reasonable additional hours" (Cooney, Howe and Murray, 2006).

the figure for all employed persons was 1,811 (OECD, 2006, p. 265, but cf. ABS, 2006j). This was broadly comparable with the United States $(1,804)$, Japan $(1,775)$ and New Zealand $(1,809)$ but ahead of the United Kingdom $(1,672)$, as well as all other EU nations. 
Other changes for full-time workers are often linked to longer hours. There has been a small decline in the proportion of full-time employees just working Monday to Friday (from 76.4 per cent in 1993 to 71.9 per cent in 2003). This seems to be mainly counterbalanced by a small increase in those working some weekends (ABS, 2003). ${ }^{12}$ Similarly, the proportion of full-time employees who say that they are "able to work extra hours in order to take time off" has increased significantly from 36.2 per cent in 1993 to 44.1 per cent in 2003 (ibid.). This is couched as an indicator of flexibility for the employee, but it is likely to be more ambiguous. Though it hints at the notion of a time-off-in-lieu (TOIL) system, it does not necessarily mean that the system is a formal one. On the contrary, evidence suggests that formal TOIL systems, such as the popular "flexitime" system in the public sector, have withered in the wake of privatization and new methods of public sector management (Heiler, 1998). ${ }^{13}$

Just as flexitime has been eroded, so too have other entitlements traditionally associated with employee-oriented flexibility. The proportion of full-time employees entitled to RDOs dropped from 35 per cent in 1993 to 26.1 per cent in 2003 (ABS, 2003). Fewer full-time employees have an entitlement to paid sick leave (ABS, 2006g). A significant proportion of full-time employees (73.5 per cent in 2006 - ABS, 2006h) claim to be able to choose when they take holidays. But the actual practice of taking annual holidays seems to be dropping, to the alarm of the tourism industry. This drop is mainly because many employees with an entitlement feel constrained in taking it up (Denniss, 2004).

Changes are also apparent for part-time employees. The increase in the proportion of the workforce engaged in long working hours is counterbalanced by the sharp growth in the part-time workforce, disproportionately composed of women and young workers. This produces what is sometimes called a "polarization" in the distribution

\footnotetext{
${ }^{12}$ A small increase in the proportion of workers doing some work on Sunday is evident from time-use data. However, Sunday work is still unusual, and it is associated with costs for workers, in particular in missing out on social activities with friends and relatives (Bittman, 2005).

${ }^{13}$ The extent of flexible work arrangements is difficult to gauge. In a recent survey, a substantial proportion of full-time employees (41 per cent) claimed to have some say in start and finish times (ABS, 2006h). But in most cases this seemed to be an informal arrangement, either exercised autonomously by the employee or arranged with the informal agreement of the employer. Only a small proportion (9.1 per cent) stated that it was associated with a formal system of flexible hours.
} 
of weekly hours, whereby the phenomenon of "overemployment" is matched by a growth of short-hours work that is often “underemployment” (Campbell, 2007).

Part of the story of part-time work in Australia concerns casual status. As part-time work increased, much of it was channelled into casual status. This offered strong advantages to employers. Though subject to some protective regulation (minimum start times, sometimes penalty rates for non-social periods), casual work lacked most of the conventional protections provided by working-time regulation. It thereby offered employers access to a powerful form of flexible working-time arrangement. Casual work could be used for small parcels of work, often at inconvenient times, and it could be used as a convenient reserve for occasions when demand might increase. A central feature was the ability to determine the number and timing of hours and to alter these at short notice (including reduce to zero). At the extreme, casual work shaded off into on-call arrangements, where labour time seemed available to employers on demand. Because women were disproportionately involved in part-time work, the story of casual status was - at least at first - a story of discrimination against women.

How these deficits in protection work out in practice is highly variable. For a minority of casual part-time workers it does lead to intermittent employment and irregularity in the number and timing of working hours (ABS, 2003). In contrast to these casuals, part-time employees with permanent status seem to have access to more protections around working time. Though the detail varies according to the specific regulatory instrument, this would generally include access to regular hours and regular rosters and access to pro rata leave entitlements. But in practice, the evidence suggests substantial working-time insecurity for part-time permanent employees. This is partly an inheritance from a previous period, in which permanent part-time work was established in a segregated form, separate from standard work and without access to the full range of rights and entitlements. But it also appears to be a major product of changes initiated in the course of labour-market deregulation. It is difficult to get aggregate data, but case-study evidence in sectors such as banking, retail and hospitality points to substantial working-time changes affecting part-time permanent employees, including cocktail contracts that mix minimum hours under permanent conditions with additional hours under casual conditions, the imposition of working- 
time conditions that had traditionally been associated with casual employment (irregular hours, more frequent starts, fewer weekly hours and a greater proportion of hours worked outside ordinary hours) and a loss of penalty rates (Deery and Mahony, 1994; Whitehouse, Lafferty and Boreham., 1997; Junor, 1998; Knox, 2006).

The working-time changes discussed in this sub-section testify to a process of fragmentation, which can be added to the fragmentation already identified with the growth of non-standard types of employment. What is entailed here is a process of fracturing within particular employment categories, including within what have been regarded as the categories covering "good” jobs. For example, the increase in the proportion of full-time workers working very long hours introduces a new set of fissures within the category of standard work. Indeed, it can be argued that this splits off an important group, who should no longer be regarded as working within the framework of a standard employment relationship, as conventionally defined (Bosch, 2004). Similarly, the changes in permanent part-time work are fracturing that type of employment, marginalizing further many part-time workers.

These working-time changes appear predominantly negative, but some aspects could be viewed more benignly. Experiences can be dependent on skill levels. The spread of results-based work within skilled sections of the full-time workforce is often associated with a sense of increased individual control over working-time arrangements. Working-time conditions are sometimes linked to complex trade-offs that may be acknowledged and even enthusiastically embraced by individual workers. Thus, heavy workloads and long hours may be seen as a fair exchange for accelerated promotion or enhanced access to bonuses. The case of part-time work is more uniformly negative, with extensive concern about the poor quality of the many parttime jobs in Australia (Pocock, 2003; Watson et al., 2003). Reduced conditions seem to go hand-in-hand with reduced hours. But even here, where the trade-offs are more clearly constrained, many workers may continue to express satisfaction with the opportunity to work reduced hours. Indeed, part-time workers tend to report higher levels of job satisfaction in spite of poor terms and conditions (Wooden and Warren, 2004; Watson, 2005).

\section{[B]Wages}


Wages and incomes have been a central focus of the employment system, and this has intensified in the course of the changes over the past 15 years. However, the process of achieving wage rises has changed dramatically. The old system, based on National Wage Cases judged by the AIRC, supplemented by industry-level bargaining as well as over-award payments at enterprise level, has been replaced by a more chaotic system, in which many workers are isolated from conventional mechanisms for securing wage rises.

The 1980s were marked by a regime of wage control, which tended to depress earnings growth for many employees (though incomes could be sustained by increases in the social wage). This period was also marked by a sharp increase in inequality in earnings, as real wages for the bottom deciles declined while executives at the top end enjoyed large rises (Watson et al., 2003). The period since the early 1990s has seen a rise in nominal and real earnings for almost all workers, but with continued inequalities, including faster rates of increase for executive pay (ibid.). Among the groups that have not been able to recoup the previous losses is the bottom fifth of the full-time male workforce. For this group there has been no real wage growth since 1975 (Frijters and Gregory, 2006, p. 210).

From 1997 to 2005, the AIRC ran "Safety Net Review" cases, which, in response to submissions from interested parties such as trade unions, employer associations, governments and welfare groups, considered the appropriateness of adjustments in federal award wages. Though all federal award wage rates were adjusted, most interest focused on the federal award minimum wage rate, which can be seen as an equivalent to an (adult) minimum wage (Eyraud and Saget, 2005). ${ }^{14}$ The AIRC consistently rejected the submissions of employers and the federal government, which claimed that raising wages would impede employment opportunities, and instead it granted moderate rises in wage rates. The effect was a rise in the minimum wage in real terms by around 10.6 per cent between 1996 and 2004 (NILS, 2006, pp. 7-8). In

\footnotetext{
${ }^{14}$ Reduced rates of pay for juniors, that is, workers under 21 , are permitted. The reductions can be substantial. For example, in the Coles Supermarket Retail Award the pay rate for junior workers as a percentage of the adult rate ranged from 45 per cent (under 16) to 90 per cent (20 years). This acts as a strong incentive for the employment of juniors in low-skill jobs.
} 
the wake of the 2005 Work Choices legislation, the new body responsible for adjusting minimum pay rates (and classification scales), AFPC, handed down its first judgment in October 2006, increasing the minimum wage (AFPC, 2006). Though this judgment was initially greeted warmly, it "represented a real wage fall of 0.9 percent on average for award-reliant employees” (Peetz, 2007, p. 36). Most researchers expect the long-term effect of the introduction of the new body, operating with quite different procedures, personnel and criteria to the AIRC, to be a slowdown of wage growth among lower paid employees (Waring, de Ruyter and Burgess, 2005). Together with the indirect effects of declining union strength, this suggests stagnation at the lower end of the labour market and a continued growth in earnings inequality (Watson et al., 2003, pp. 107-131).

In spite of the fact that the minimum wage is seen as high in international comparison, concern about the "working poor" has increased, and a low pay sector, defined as comprising full-time workers whose earnings are less than $2 / 3$ of median earnings, has emerged. This sector is now relatively substantial, comprising around 14 per cent of all employees, although its size does not seem to have increased in recent years (OECD, 2006, p. 175). On the other hand, there is some evidence of poor and declining hourly wages for part-time workers compared to full-time workers. Comparison of wage rates between permanent and casual employees is more difficult, because the hourly rates mean different things for the two groups (pay for an hour of labour or pay for an hour that might be either at work or on some form of leave). Watson (2005) suggests that, in spite of the apparent effect of a casual loading, casual workers are penalized.

The issue of low earnings overlaps with irregular earnings, stemming from intermittent employment and irregular hours. This can be a particular problem for casuals, who are in jobs that are less stable. In addition, casual workers lack access to protections that can smooth earnings and are only paid for the hours they are at work. As a result, they are vulnerable to employer decisions to change the number of hours and also vulnerable to the intervention of outside events such as public holidays, annual plant closedown, sickness and personal emergencies. 
The share of national income going to wages is continuing to decline. At 53.6 per cent of total factor income in 2006, the wages share is at its lowest level since June 1970. On the other hand, the profit share, currently standing at 26.8 per cent of total factor income, is at its highest level since the start of the series in 1960 (ABS, 2006f).

\section{[B]Gender equality and work-family balance}

Pressures for gender equity arise from different sources, but one powerful source is the increased employment rates for women. A substantial part of this increase flows in to full-time work, but, as noted above, another substantial part, especially women with dependent children, is taken up in part-time jobs.

There is a mixed record of achievement in gender equity. One long-term trend is towards more equal access to higher education and to professional jobs. Another important trend is towards a decrease in overt discrimination against women. The labour regulation system, in its earliest form, was built up around a male breadwinner/female homemaker model, which incorporated discriminatory provisions against women. Thus wages for men were framed as a family wage, while wages for women were set at a lesser rate (Whitehouse, 2004). Similarly, some awards or regulations inserted bars on the employment of married women. Overt discrimination in wage rates persisted for several decades, but was removed in a series of equal pay judgments from the industrial tribunals in the early 1970s, while marriage bars disappeared in the 1960s and 1970s. As a result of these initiatives, the gender pay gap narrowed - though it never completely disappeared - and Australia moved ahead of many other nations on this important indicator of gender equity (see Figure 4.6).

\section{FIGURE 4.6 ABOUT HERE}

The achievements of the early 1970s pointed to the positive potential of the award system as a vehicle for promoting gender equity. This positive potential was further taken up in subsequent years, with several Test Cases, culminating in the Family Provisions Test Case in 2004 to 2005. Action by the tribunals was supplemented by 
legislative initiatives, in areas such as sex discrimination and equal employment opportunity.

However, these advances have stalled in the most recent period. Gender occupational segregation persists, with women concentrated within a narrow band of occupations in the service sector (Grimshaw, Whitehouse and Zetlin, 2003). There has been little progress in improving the quality of the part-time jobs that many women have taken up. As noted above, the majority of these part-time jobs are casual and there are signs of a deterioration of conditions even among “permanent” part-time jobs. There has been little movement towards narrowing the remaining gender pay gap, and indeed much contemporary commentary focuses on the threat of a widening gap. The aggregate data confirm the impression of stasis (Figure 4.7). Preston (2007) suggests that underneath the aggregate figures is a range of gender pay gaps that exhibit worrying trends. Included here are the gaps according to part-time status and casual status. Different methods of pay determination can also affect the gap, disadvantaging female employees concentrated in the award-reliant sector. Preston (2007) suggests that the widespread fears that women would lose out in labour-market deregulation are proving to be well justified.

\section{FIGURE 4.7 ABOUT HERE}

The issue of gender equality can be seen to overlap with the issue of work/family or work/life balance. More people with caring responsibilities are in the workplace, yet workplaces remain relatively inflexible and resistant to accommodating the needs of employees. The connection between the sphere of paid work and the sphere of life outside has become increasingly a site of pressure or, as one author puts it, a site of collision (Pocock, 2003). The precise pressures on employees take different forms (Campbell and Charlesworth, 2004, pp. 38-39). They are experienced in different ways at different phases of the life course, but they appear particularly strong around the birth and care of young children.

Australia is faring poorly in handling these pressures. This is evident in data on workforce participation, including the large drop in participation for mothers of young children, and in the evidence of mounting public concern with work/family balance. 
The pressures can be eased somewhat by what are called family-friendly measures at the workplace. Particularly important are short-term and long-term leave arrangements, good quality part-time work and employee-oriented flexible work arrangements. Five points seem to be widely accepted in the literature on familyfriendly benefits in Australia: (a) family-friendly benefits are provided through a patchwork of different methods; (b) though it is difficult to make exact estimates, most family-friendly benefits provided through firm-level initiatives seem to be available only to a minority of employees, predominantly composed of higher-skilled workers in large and public sector enterprises; (c) casual employment represents a significant gap in eligibility for family-friendly benefits; (d) there are problems with the quality of part-time employment, thereby limiting its claim to be family-friendly; and (e) even among those who are formally eligible for family-friendly benefits, there are substantial difficulties in take up as a result of factors such as unsupportive organizational cultures, long hours and work intensification (ibid., pp. 42-50).

Though family-friendly measures can be found in selected firms, the missing element in Australia is the initiative to ensure that they are generalized through the workforce. The most glaring example is paid maternity leave. Australia remains one of only two OECD countries - the other is the US - without a national paid maternity leave scheme. The spread of such measures has been impeded by the attitude of past federal governments and by the dominant labour regulation arrangements, which treat such measures as an item to be granted or denied according to the choice of the employer. At the same time, concern is growing that labour-market deregulation may be helping to spread what can be called "family-hostile" measures such as arbitrary management, poor working-time schedules and casual employment conditions.

\section{[B]Health and safety}

Health and safety is largely regulated by independent statutes, developed at state rather than federal level. All states have reasonably comprehensive legislation, modelled on the principles established in the early 1970s by the Robens Report in the United Kingdom (Creighton and Stewart, 2005, pp. 584-618). This system has been so far spared the direct changes pursued so vigorously at federal level, and it remains effective in inhibiting dangerous and unsafe practices in many workplaces. 
In 2003 to 2004 there were 332 work-related traumatic injury fatalities in Australia, equal to a rate of 3.5 for every 100,000 members of the employed civilian labour force (ASCC, 2006b, p. 17), which is somewhat lower than the estimated average for the established market economies of 4.2 fatal occupational accidents for every 100,000 workers (Hämäläinen, Takala and Saarala, 2006, p. 145).

Recent ABS data suggest that 6.4 per cent of all people who worked at some time during the 12 months from 2005 to 2006 experienced a work-related injury or illness during that period. The most common types of injury or illness were sprains or strains, followed by cuts or open wounds, and chronic joint or muscle conditions. Over half (58 per cent) took some time off work, with 28 per cent taking five days or more off work (ABS, 2006d). Australia has the world's highest incidence rate of malignant mesothelioma, a fatal form of cancer. Incidence rates have been increasing since 1965 and it is believed these high rates are related to the extensive use and production of asbestos in past decades (NOHSC, 2004).

We can draw some information on trends from data for workers' compensation, though these are limited by the circumstances of their collection. The incidence rate of compensated work-related fatalities fell from 5.4 to 2.9 per 100,000 employees between 1996 to 1997 and 2002 to 2003, suggesting that Australian workplaces may have become safer since 1996. Similarly, the incidence rate for compensated workrelated injury or disease fell from 23 to 17 claims per 1,000 employees over the same period (ASCC, 2006a; b). Compensation claims for almost all nature of injury and illness have decreased over the seven-year period to 2002 to 2003, with the major exception of mental disorders, which increased by 37 per cent. Among the actions or events causing the injury or illness, mental stress was the only one that increased between 1996 to 1997 and 2002 to 2003 (ASCC, 2006a, pp. 28, 30).

In spite of this overall positive assessment, concern is mounting about some of the implications of changing labour regulation and changing work patterns. The current regulatory system gives an important role to employee safety representatives and management-employee safety committees, and these are threatened by the federal restrictions on trade union action and participation at the workplace. In addition, the 
federal government is promising a national approach, which would displace the state systems of occupational health and safety.

The consequences of the growth of certain forms of non-standard employment, especially in areas such as road transport and construction, has been one focus of recent research (Quinlan, 2003; Johnstone and Quinlan, 2005). Workers in nonstandard forms of employment such as casual work and agency work seem more vulnerable to accidents and occupational illnesses. The growth of casual employment has been identified in particular with significant hidden health and safety costs (McNamara, 2006). Similarly, the issue of job stress has attracted increasing attention in recent years. A major study in the state of Victoria (La Montagne et al., 2006) used a measure of job stress developed from the Karasek demand/control model, together with data from an empirical study of over 1,000 working Victorians. The study showed that job stress was making a major contribution to ill health, including cardiovascular disease and depression, and that the most vulnerable groups were those with high demands and low control in their job.

\section{[A]4. New issues and social debates}

The debate on changing employment conditions in Australia is growing. In the 1980s, a broad consensus about the deficiencies of the previous employment regime and the need to create a more open economy underpinned the policy discussion. However, as government initiatives extended from product and financial markets to labour markets, and as the outcomes for individual workers became clearer, more disquiet has emerged.

Discussion and debate on changing employment conditions cover a range of issues, some familiar in other countries, some less familiar. The "ageing society" is the subject of an emerging background debate. Unemployment and joblessness is a traditional concern, linked in to policy discussion around wages policy and social security. Low-paid work is a concern for some, though others argue that earnings inequality is less significant than income inequality and that in any case low-paid workers are not necessarily in low-paid households. Concerns around non-standard employment, including in particular casual employment, working-time patterns and 
job quality, have been staples of labour-market research and public discussion for the past ten years. This research is now voluminous, but it has had little impact so far on policy. Responses from government officials, often backed up by commentators from right-wing think tanks, have typically conceded the facts but sought to deny the policy implications, often shifting the subject either to the more flattering data on macroeconomic indicators or to attitudinal data suggesting that most workers are relatively satisfied with their jobs (Australian Government, 2003).

One crucial current debate concerns productivity growth. A key rationale for neoliberal policy changes to labour regulation was the need to boost lagging productivity growth. Some economists have drawn attention to data for changes in multi-factor productivity in the mid- to late 1990s. They argue that there was a "productivity surge” that could be plausibly linked to labour-market reforms, providing potent evidence for the value of the policy changes of the early 1990s (Parham, 2000, p. 2005). Subsequent discussion has challenged this view, and the evidence now looks questionable: the rate of growth of multi-factor productivity has retreated in the subsequent years, in spite of the continuation of labour-market reforms. Critics suggest that even the growth in the earlier period is something of a statistical illusion (Hancock, 2005; Quiggin, 2006). Quiggin (2006) argues that it is at best a temporary blip, most plausibly related to temporary factors such as recovery from the recession and unsustainable increases in work intensity. The debate on productivity extends into a discussion of the likely impact of current and prospective changes on productivity (Burgess and Waring, 2005). In particular attention has been given to the impact of individual contracting on productivity, but the verdict seems to be negative (Peetz, 2006).

Also important is a current debate on skill shortages. The conventional view in business circles sees evidence of large-scale shortages and over-full employment in many areas. As in the case of the debate on the "ageing society", this is in turn seen as necessitating mobilization of reserves of labour. For employers concerned with skill shortages, the immediate remedy tends to be sought in immigration policy, through calls to boost immigrant numbers, to broaden the categories defined as skilled in the general skilled migration programme, and to allow easier access to temporary migrant workers. On the other hand, critics have suggested that talk of tight labour markets is 
often exaggerated. The notion of "skill shortage" is slippery (Richardson, 2007). Skill shortages are real, but some can be related back to the impact of specific employer practices, including the employer retreat from training, especially apprenticeships in skilled trades, and the degradation of job quality in areas such as nursing and maintenance work (Watson et al., 2003, pp. 151-164). A market approach to training has been dominant for the past ten years, but it now seems to be running up against its limits (Hall and Lansbury, 2006).

One element of the debate on skill shortages concerns its possible effect as a countervailing pressure on the impact of recent changes in labour regulation. It is sometimes suggested that skill shortages could make employers "wary of being seen to cut conditions for fear of being unable to attract or retain good staff”' (Stewart, 2006, pp. 53-54). Again it is useful to be cautious. Though labour shortages are a major issue in certain trades and professions, and in certain geographic areas, they may not be as widespread as is often feared. It is hard to resist the conclusion that labour and skill shortages are unevenly distributed, and skill shortages can "still coexist with plentiful labour supply in low-pay labour markets” (Briggs and Buchanan, 2005, p. 185). Nor is the link between skill shortages and employer caution as straightforward as is often suggested. Certainly skill is vital in giving workers some bargaining strength, and skill shortages may slow down employer initiatives. However, the key pressures on employers derive from product markets, and there is a danger that competitive advantages secured by one employer as a result of reduced wages and conditions will force other employers to follow suit (Briggs, 2005).

Employer strategies have not received the attention they deserve, and in a more deregulated environment these may come even more to the fore. There is some concern that changing financial markets and the dominance of "shareholder value" have shaped employer strategies and pushed them too far in the direction of the pursuit of short-term gains (Watson et al., 2003). This concern is growing, as financial markets again experience the return of leveraged buyouts from private equity groups.

The policy settings of the last ten years remained fixed while the federal Coalition government was fixed in office. Alternative principles and policies have been slow to emerge, but a few signs can be detected. States such as Victoria have experimented 
with new initiatives to restore regulatory protection. At the crucial federal level, awareness that the most recent changes do not involve "deregulation” but rather just different, often highly prescriptive, regulation, has helped to focus interest in the possibility of different regulatory principles. Similarly, the almost-complete demise of the old system of awards has cleared the way for some new thinking. A simple defence of traditional institutions and achievements is no longer practicable or plausible. Instead, critics are obliged to put forward their ideas on alternative paths towards modernization of the employment system. Inspired by this logic, the central trade union body, working in close collaboration with the Labor Party, developed a model for an altered labour regulation system at the federal level. This would be based on a stronger floor of minimum conditions and provisions for union recognition in order to support single-employer collective bargaining, though it would still stop short of full support for multi-employer collective bargaining (ACTU, 2006; see Briggs, 2007). Some social-democratic circles have sought to develop the European ideas of transitional labour markets (Howe, 2007). Similarly the Human Rights and Equal Opportunities Commission (HREOC) has sought to intervene in the work/family debate with a major report that supports the "valued care/shared work" model (HREOC, 2007). These are important straws in the wind, though the gulf between the world of research and the world of policy is yet to be bridged.

The new federal Labor government is entering office with a policy that promises to remove the worst excesses of Work Choices (ALP 2007), for example by restoring unfair dismissal rights and by removing opportunities for employers to lower conditions through AWAs. However, it seems likely that the Labor government will retain several aspects of the regulatory framework introduced by the previous government. Much will depend on the unfolding of debate and discussion in the next few years.

\section{[A]5. Conclusions}

The distinctive employment system that characterized Australia for much of the twentieth century is changing. The story of employment conditions is mixed. The positive results promised by labour-market deregulation seem difficult to identify. But there are some positive signs in the labour markets that seem propelled by other 
factors, including in particular the wave of economic prosperity experienced since the mid-1990s.

The most striking aspect of change concerns labour regulation, which has shifted slowly but surely away from traditional principles of security for employees towards promotion of increased labour-market flexibility for employers. Australia offers a radical case of labour-market deregulation, inspired by neoliberal principles. The employment system needed to be modernized, in response to changed economic and political conditions and globalization, but the direction of change seems poorly chosen. There are few signs of the promised benefits in terms of productivity growth. Moreover, the outcome seems a puzzle as well as a disappointment. Instead of the simple, transparent and open system promised by ideals of deregulation, the outcome seems complex and contradictory. It presents an ongoing challenge for reform.

\section{Acknowledgements}

Thanks to Fiona Macdonald for help with the data on health and safety and to Gillian Whitehouse for providing data on trends in the gender wage gap. Thanks to Sara Charlesworth, Sally Weller, Woo Cho, François Eyraud, Sangheon Lee and the anonymous referees for helpful comments on earlier drafts. 


\section{References}

ABS (Australian Bureau of Statistics). 2006a. Australian Labour Market Statistics, cat. no. 6105.0, July, data cubes.

----. 2006b. Australian labour market statistics, cat. no. 6105.0, Oct.

----. 2006c. Australian labour market statistics, cat. no. 6105.0, April, data cubes.

----. 2006d. Work-related injuries, Australia, cat. no. 6342.0.

----. 2006e. Labour statistics: Concepts, sources and methods, cat. no. 6102.0.55.001, Aug.

----. 2006f. Australian system of national accounts, 2005-06, cat. no. 5204.0.

----. 2006g and various issues. Employee earnings, benefits and trade union membership, Australia, cat. no. 6310.0.

----. 2006h. Working time arrangements, Australia, cat. no. 6342.0, Nov.

----. 2006i and various issues. Employee earnings and hours, Australia, cat. no. 6306.0, May.

----. 2006j. Information paper: Implementing new estimates of hours worked into the Australian national accounts, cat. no. 5204.0.55.003.

----. 2003 and various issues. Working arrangements, Australia, cat. no. 6342.0.

----. 1990. Award coverage, Australia, cat. no. 6315.0.

ACIRRT (Australian Centre for Industrial Relations Research and Training). 1999. Australia at work: Just managing?( Sydney, Prentice Hall).

ACTU (Australian Council of Trade Unions). 2006. A fair go at work: Collective bargaining for Australian workers, Sep. (Melbourne).

AFPC (Australian Fair Pay Commission). 2006. Wage-setting decision and reasons for decision (Melbourne).

ALP (Australian Labor Party). 2007. Forward with Fairness: Labor's plan for fairer and more productive Australian workplaces, April (Canberra).

ASCC (Australian Safety and Compensation Council). 2006a. Compendium of workers' compensation statistics Australia 2003-04 (Canberra).

----. 2006b. Estimating the number of work-related traumatic injury fatalities in Australia 2003-2004 (Canberra).

Australian Government. 2003. Good jobs or bad jobs: An Australian policy and empirical perspective (Canberra, Department of Employment and Workplace Relations).

Baird, M. 2005. "Parental leave in Australia: The role of the industrial relations system", in Law in Context, Vol. 23, No. 1, pp. 45-64.

Bell, S. 1997. Ungoverning the economy: The political economy of Australian economic policy (Melbourne, Oxford University Press).

Bennett, L. 1994. Making labour law in Australia: Industrial relations, politics and law (Sydney, Law Book Company).

Bittman, M. 2005. "Sunday working and family time”, in Labour and Industry, Vol. 16, No. 1, pp. 59-81. 
Borland, J.; Gregory, B.; Sheehan, P. (eds). 2001. Work rich, work poor: Inequality and economic change in Australia (Melbourne, Centre for Strategic Economic Studies).

Bosch, G. 2004. "Towards a new standard employment relationship in Western Europe?”, in British Journal of Industrial Relations, Vol. 42, No. 4, pp. 617636.

Briggs, C. 2007. "Statutory union recognition in North America and the UK: Lessons for Australia?”, in The Economic and Labour Relations Review, Vol. 17, No. 2, pp. 77-97.

----. 2005. Federal IR reform: ThesShape of things to come (Sydney, ACIRRT).

Briggs, C.; Buchanan, J. 2005. "Work, commerce and the law: A new Australian model?”, in The Australian Economic Review, Vol. 38, No. 2, pp. 182-191.

Buchanan, J.; van Wanrooy, B.; Condidine, J.; Bretherton, T. 2006. Longer and irregular hours: Employers, decentralised bargaining and working time standards in Australia since the late 1970s, paper for the New Standards for New Times? conference, Melbourne, 22-23 June.

Burgess, J.; Waring, P. 2005. “The productivity question”, in C. Sheil (ed.): The state of the states 2005: The state of industrial relations (Sydney, Evatt Foundation), pp. 53-65.

Campbell, I. 2007. "Long working hours in Australia: Working-time regulation and employer pressures”, in The Economic and Labour Relations Review, Vol. 17, No. 2, pp. 37-68.

----. 2004. “Casual work and casualisation: How does Australia compare?”, in Labour and Industry, Vol. 15, No. 2, pp. 8 -111.

Campbell, I.; Brosnan, P. 1999. "Labour market deregulation in Australia: The slow combustion approach to workplace change", in International Review of Applied Economics Vol. 13, No. 3, pp. 353-394.

Campbell, I.; Burgess, J. 2001. "Casual employment in Australia and temporary work in Europe: Developing a cross-national comparison”, in Work, Employment \& Society, Vol. 15, No. 1, pp. 171-184.

Campbell, I.; Charlesworth, S. 2004. Background report: Key work and family trends in Australia (Melbourne, Centre for Applied Social Research, RMIT University).

Castles, F. 1985. The working class and welfare (Wellington, Allen and Unwin).

Chapman, A. 2006. "Unfair dismissal law and Work Choices: From safety net standard to legal privilege”, in The Economic and Labour Relations Review, Vol. 16, No. 2, pp. 237-264.

Clegg, H. 1976. Trade unionism under collective bargaining (Oxford, Basil Blackwell).

Coe, N.; Johns, J.; Ward, K. 2007. Agents of casualisation? Slow growth, fragmented markets and competitive margins in the Australian temporary staffing industry, Globalisation of the temporary staffing industry Working Paper no.

4, Geography, School of Environment and Development, University of Manchester.

Cooney, S.; Howe, J.; Murray, J. 2006. ““'Time and money under work choices: Understanding the new Workplace Relations Act as a scheme of regulation”“, in University of New South Wales Law Journal, Vol. 29, No. 1, pp. 215-241.

Creighton, B.; Stewart, A. 2005. Labour law, 4th edn (Sydney, TheFederation Press).

Deery, S.; Mahony, A. 1994. "Temporal flexibility: Management strategies and employee preferences in the retail industry", in Journal of Industrial Relations, Vol. 36, No. 3, pp. 332-352. 
Denniss, R. 2004. "Paid annual leave in Australia: An analysis of actual and desired entitlements", in Labour and Industry, Vol. 15, No. 1, pp. 1-16.

----. 2001. Measuring employment in the 21st century: New measures of underemployment and overwork, Discussion Paper no. 36, Canberra, The Australia Institute.

Eyraud, F.; Saget, C. 2005. The fundamentals of minimum wage fixing (Geneva, ILO).

Fenwick, C. 2006. "How low can you go? Minimum working conditions under Australia's new labour laws”, in The Economic and Labour Relations Review, Vol. 16, No. 2, pp. 85-126.

Freyens, B.; Oslington, P. 2005. “The likely employment impact of removing unfair dismissal protection”, in Journal of Australian Political Economy, No. 55, pp. 56-65.

Frijters, P.; Gregory, R. 2006. “From golden age to golden age: Australia’s 'great leap forward'?”, in The Economic Record Vol. 82, pp. 207-224.

Grimshaw, D.; Whitehouse, G.; Zetlin, D. 2003. "Changing pay systems, occupational concentration and the gender pay gap: Evidence from Australia and the UK", in Industrial Relations Journal, Vol. 32, No. 3, pp. 209-229.

Hall, R. 2006. “Temporary agency work and HRM in Australia”, in Personnel Review, Vol. 35, No. 2, pp. 158-174.

Hall, R.; Lansbury, R. 2006. "Skills in Australia: Towards workforce development and sustainable skill ecosystems”, in Journal of Industrial Relations, Vol. 48, No. 5, pp. 575-592.

Hämäläinen, P.; Takala, J.; Saarala, K.L. 2006. “Global estimates of occupational accidents”, in Safety Science, Vol. 44, pp. 137-156.

Hancock, K. 2005. "Productivity growth in Australia 1964-65 to 2003-04”, in Australian Bulletin of Labour, Vol. 31, No. 1, pp. 28-32.

Heiler, K. 1998. "What has happened to standard hours of work in Australia? Or do we need to bring back the bundy clock?”, in B. Cass and R. Crouch (eds): Divided work/divided society: Employment, unemployment and income distribution in 1990s Australia (Sydney, RIHSS), pp. 75-99.

Howe, B. 2007. Weighing up Australian values: Balancing transitions and risks to work and family in modern Australia (Sydney, University of New South Wales Press).

HREOC (Human Rights and Equal Opportunity Commission). 2007. It's about time: Women, men, work and family, Final Paper (Sydney).

International Labour Office (ILO). 2005. Key indicators of the labour market, 4th edn (Geneva).

Johnstone, R.; Quinlan, M. 2005. The OHS regulatorycChallenges posed by agency workers: Evidence from Australia, Canberra, National Research Centre for OHS Regulation, Australian National University, Working Paper no. 38.

Junor, A. 1998. "Permanent part-time work: New family-friendly standard or high intensity cheap skills?”, in Labour \& Industry, Vol. 8, No. 3, pp. 77-95.

Knox, A. 2006. "The differential effects of regulatory reform: Evidence from the Australian luxury hotel industry”, in Journal of Industrial Relations, Vol. 48, No. 4, pp. 453-474.

LaMontagne, A.; Shaw, A.; Ostry, A.; Louie, A.; Keegel, T. 2006. Workplace stress in Victoria - developing a systems approach: Full report, Victorian Health Promotion Foundation, Melbourne.

Laplagne, P.; Glover, M.; Fry, T. 2005. ThegGrowth of labour hire employment in Australia, Productivity Commission Staff Working Paper, Melbourne, Feb. 
Lee, S. 2004. "Working hour gaps: Trends and issues”, in J. Messenger (ed.): Working time and workers' preferences in industrialized countries: Finding the balance (London, Routledge), pp. 29-59.

Lloyd, C. 2002. "Regime change in Australian capitalism: Towards a historical political economy of regulation”, in Australian Economic History Review, Vol. 42, No. 3, pp. 238-266.

Louie, A.; Ostry, A.; Quinlan, M.; Keegel, T.; Shoveller, J.; LaMontagne, A. 2006. "Empirical study of employment arrangements and precariousness in Australia”, in Relations Industrielles/Industrial Relations, Vol. 61, No. 3, pp. 465-489.

McNamara, M. 2006. The hidden health and safety costs of casual employment, Industrial Relations Research Centre paper, University of New South Wales, Sydney.

Mitchell, R.; Campbell, R.; Barnes, A.; Bicknell, E.; Creighton, K.; Fetter, J.; Korman, S. 2005. "What's going on with the "No Disadvantage Test"? An analysis of outcomes and processes under the Workplace Relations Act 1996 (Cwlth)", in Journal of Industrial Relations, Vol. 47, No. 4, pp. 393-423.

Murray, J. 2005. “The AIRC’s Test Case on Work and Family Provisions: The end of dynamic regulatory change at the federal level?", in Australian Journal of Labour Law, Vol. 18, No. 3, pp. 325-343.

NILS (National Institute of Labour Studies). 2006. "Labour market and institutional developments: Australia”, June, posted to Global Policy Network, http://www.gpn.org [14 Nov. 2006].

NOHSC (National Occupational Health and Safety Commission). 2004. The incidence of Mesothelioma in Australia 1999 to 2001: The Mesothelioma register report 2004 (Canberra).

O'Donnell, A. 2005. Re-inventing unemployment: Welfare reform as labour market regulation, Working Paper no. 36, Melbourne, Centre for Employment and Labour Relations Law, University of Melbourne.

----. 2004. "Non-standard” workers in Australia: Counts and controversies”, in Australian Journal of Labour Law, Vol. 17, pp. 1-28.

OECD. 2006. OECD employment outlook: Boosting jobs and incomes (Paris).

----. 2004. "Employment protection regulation and labour market performance", in OECD Employment Outlook (Paris), pp. 61-116.

Parham, D. 2005. “Australia’s 1990s productivity surge: A response to Keith Hancock's challenge”, in Australian Bulletin of Labour, Vol. 31, No. 3, pp. 295-303.

----. (2000) “A more productive Australian economy”, in Agenda, Vol. 7, pp. 3-16.

Peetz, D. 2007. Assessing the impact of "WorkChoices” one year on, Report to Department of Innovation, Industry and Regional Development, Melbourne, Victorian Government.

----. 2006. Brave new workplace: How individual contracts are changing our jobs (Sydney, Allen and Unwin).

Pocock, B. 2003. The work/lifecCollision: What work is doing to Australians and what to do about it (Sydney, The Federation Press).

Pocock, B.; Buchanan, J.; Campbell, I. 2004. "Meeting the challenge of casual work in Australia: Evidence, past treatment and future policy", in Australian Bulletin of Labour, Vol. 30, No. 1, pp. 16-32.

Preston, A. 2007. untitled, Submission to Australian Fair Pay Commission. 
Productivity Commission. 2006. The role of non-traditional work in the Australian labour market, Commission Research Paper, Melbourne, May.

Quiggin, J. 2006. “Stories about productivity”, in Australian Bulletin of Labour, Vol. 32, No. 1, pp. 18-26.

Quinlan, M. 2003. Flexible work and organisational arrangements - regulatory problems and responses, Canberra, National Research Centre for OHS Regulation, Australian National University, Working Paper no. 16.

Richardson, S. 2007. What is a skill shortage? (Adelaide, NCVER).

Schmid, G.; Gazier, B. (eds). 2002. The dynamics of full employment: Social integration through transitional labour markets (Cheltenham, Edward Elgar).

Stewart, A. 2006. "Work choices in overview: Big bang or slow burn?”, in The Economic and Labour Relations Review, Vol. 16, No. 2, pp. 25-60.

----. 2002. "Redefining employment? Meeting the challenge of contract and agency labour”, in Australian Journal of Labour Law, Vol. 15, No. 3, pp. 235-276.

Supiot, A. 2001. Beyond employment: Changes in work and the future of labour law in Europe (Oxford, Oxford University Press).

Sutherland, C. 2007. "All stitched up? The 2007 amendments to the safety net”, in Australian Journal of Labour Law, (forthcoming).

Traxler, F.; Blaschke, S.; Kittel, B. 2001. National labour relations in internationalized markets: A comparative study of institutions, change, and performance (Oxford, Oxford University Press).

van Wanrooy, B.; Oxenbridge, S.; Buchanan, J.; Jakubauskas, M. 2007. Australia@Work: The benchmark report, Workplace Research Centre, University of Sydney, Sep.

Waring, P.; de Ruyter, A.; Burgess, J. 2005. “Advancing Australia fair: The Australian Fair Play and Conditions Standard”, in Journal of Australian Political Economy, No. 55, pp. 105-125.

Watson, I. 2000. "Beyond the unemployment rate: Building a set of indices to measure the health of the labour market”, in Australian Bulletin of Labour, Vol. 26, No. 3, pp. 175-190.

----. 2005) "Contented workers in inferior jobs? Re-assessing casual employment in Australia”, in Journal of Industrial Relations, Vol. 47, No. 4, pp. 371-392.

Watson, I.; Buchanan, J.; Campbell, I.; Briggs, C. 2003. Fragmented futures: New challenges in working life (Sydney, The Federation Press).

Whitehouse, G. 2004. "From family wage to parental leave: The changing relationship between arbitration and the family", in Journal of Industrial Relations, Vol. 46, No. 4, pp. 400-412.

Whitehouse, G.; Lafferty, G.; Boreham, P. 1997. "From casual to permanent parttime? Non-standard employment in retail and hospitality", in Labour and Industry, Vol. 8, No. 2, pp. 33-48.

Whitehouse, G.; Baird, M.; Diamond, C.; Soloff, C. 2007. "Parental leave in Australia: Beyond the statistical gap”, in Journal of Industrial Relations, Vol. 49, No. 1, pp. 103-112.

Wooden, M.; Sloan, J.; Kennedy, S.; Dawkins J.; Simpson, M. 1994. Work sharing and unemployment, NILS Working Paper no. 129 (Adelaide).

Wooden, M.; Warren, D. 2003. The characteristics of casual and fixed-term employment: Evidence from the HILDA survey, Melbourne Institute Working Paper No. 15/03 (University of Melbourne). 
Wooden, M.; Warren, D. 2004. "Non-standard employment and job satisfaction: Evidence from the HILDA survey", in Journal of Industrial Relations, Vol. 46, No. 3, pp. 275-297. 
TABLES AND FIGURES

Table 4.1. Award coverage rates, public and private sectors, May 1990 (proportion of employees)

\begin{tabular}{|l|l|l|l|}
\hline & $\begin{array}{l}\text { Covered by awards } \\
\text { determinations and } \\
\text { collective } \\
\text { agreements }\end{array}$ & Not covered & Total (000) \\
\hline & & & 1694.8 \\
\hline Public & 97.8 & 2.2 & 3957.4 \\
\hline Private & 72.4 & 27.6 & 5652.2 \\
\hline & & & \\
\hline All sectors & 80.0 & 20.0 & \\
\hline
\end{tabular}

Source: ABS, 1990.

Table 4.2. Methods of setting pay, public and private sectors, May 2006 (proportion of employees)

\begin{tabular}{|l|l|l|l|l|l|l|}
\hline & $\begin{array}{l}\text { Award } \\
\text { only }\end{array}$ & \multicolumn{2}{l|}{ Collective agreement } & \multicolumn{2}{l|}{ Individual arrangement } \\
\hline & & Registered & $\begin{array}{l}\text { Unregistere } \\
\text { d }\end{array}$ & Registered & Unregistered & $\begin{array}{l}\text { Working } \\
\text { proprietor of } \\
\text { incorporated } \\
\text { business }\end{array}$ \\
\hline & & & & & & \\
\hline Public & $2.4^{*}$ & 92.9 & $0.2^{*}$ & 2.0 & 2.6 & - \\
\hline Private & 23.1 & 24.4 & 3.8 & 3.3 & 39.0 & 6.3 \\
\hline & & & & & & \\
\hline All sectors & & & & & & \\
\hline Male & 14.7 & 34.6 & 3.3 & 3.6 & 36.6 & 7.2 \\
\hline Female & 23.4 & 41.7 & 2.8 & 2.5 & 26.7 & 2.9 \\
\hline Persons & 19.0 & 38.1 & 3.0 & 3.1 & 31.7 & 5.1 \\
\hline
\end{tabular}

Notes: * Estimate has a relative standard error of $25-50 \%$ and should be used with caution.

${ }^{1}$ Owner-managers of incorporated enterprises are encompassed by the standard definition of employee in Australia and therefore also find their way into these data. They are placed in a separate column here, but in previous surveys in 2000 and 2002 they were classified to "unregistered individual arrangements".

Source: ABS, 2006i. 
Table 4.3. Employed persons by full-time and part-time status, ${ }^{1}$ by sex, 1994 2005

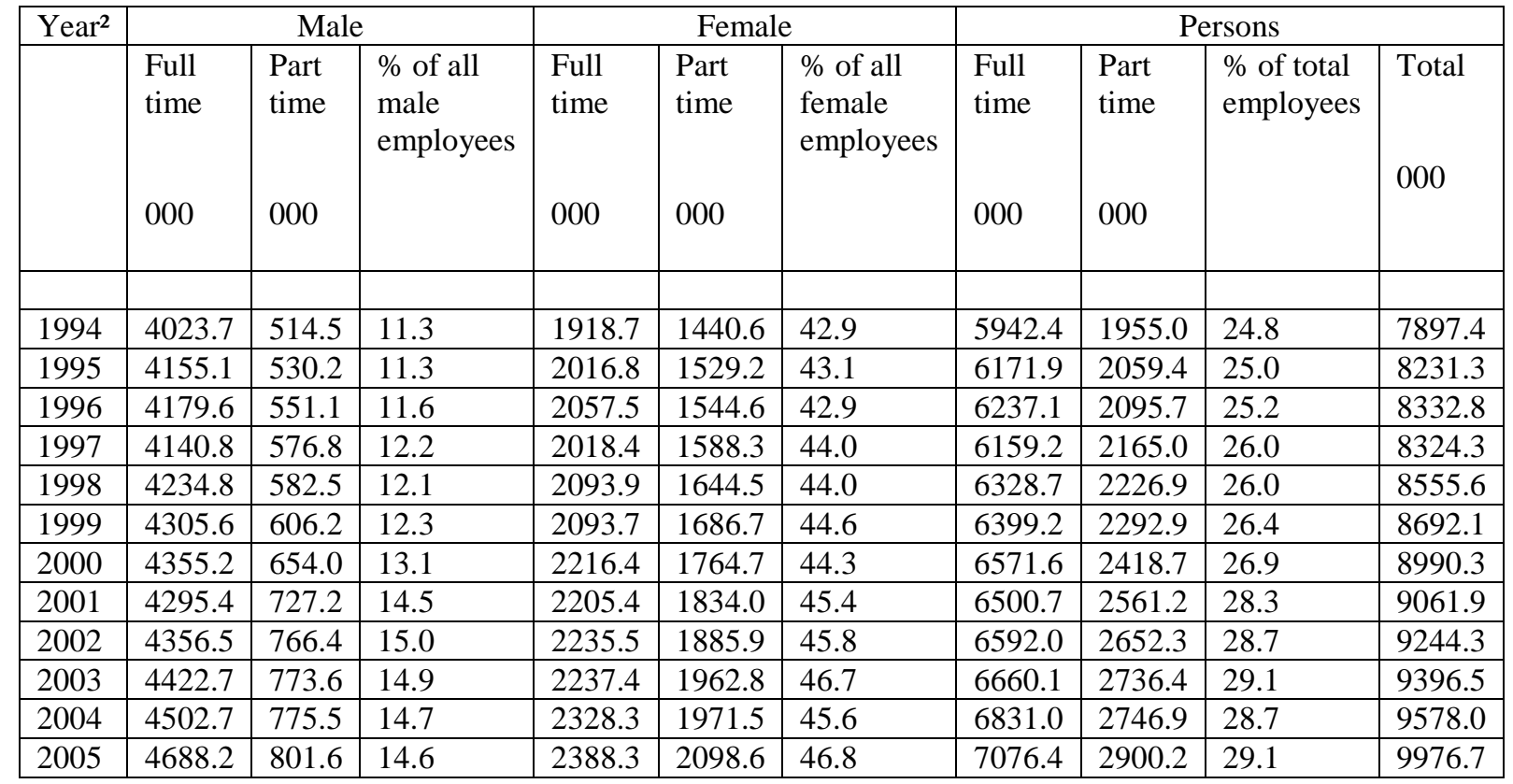

Notes; ${ }^{1}$ Persons employed full time are those who usually worked 35 hours or more a week (in all jobs) and those who, although usually working less than 35 hours a week, worked 35 hours or more during the reference week; persons employed part time are those employed persons who usually worked less than 35 hours a week (in all jobs) and either did so during the reference week, or were not at work in the reference week.

${ }^{2}$ August.

Source: ABS 2006a.

Table 4.4. Different types of employment, Australia 2007 (\% of workforce)

\begin{tabular}{|l|c|c|c|c|c|}
\hline \multirow{2}{*}{$\begin{array}{l}\text { Weekly } \\
\text { hours }\end{array}$} & \multicolumn{5}{|c|}{ Employees } \\
\cline { 2 - 6 } & Permanent & Casual & $\begin{array}{l}\text { Fixed } \\
\text { term }\end{array}$ & Contractors & $\begin{array}{l}\text { Non- } \\
\text { contractors }\end{array}$ \\
\hline Full time & $48.6^{*}$ & 3.6 & 3.5 & & \\
\hline Part time & 12.3 & 15.2 & 1.7 & & \\
\hline Total & 61.0 & 18.8 & 5.3 & $\begin{array}{c}8.9 \\
(2.6) \#\end{array}$ & 5.9 \\
\hline
\end{tabular}

Notes: *Standard employment

\#Dependent contractors

Source: Van Wanrooy et al., 2007, p. 20 (with additional data supplied on request). 
Table 4.5. Full-time employees ${ }^{1}$, whether overtime worked on a regular basis and whether overtime is paid or not paid, 1993-2003 (\%)

\begin{tabular}{|l|l|l|l|l|l|}
\hline Year $^{2}$ & $\begin{array}{l}\text { Full-time } \\
\text { employees } \\
\text { working } \\
\text { overtime }\end{array}$ & $\begin{array}{l}\text { Paid for } \\
\text { overtime }\end{array}$ & Not paid $^{3}$ & $\begin{array}{l}\text { Permanent } \\
\text { full-time } \\
\text { employees } \\
\text { working } \\
\text { overtime }\end{array}$ & $\begin{array}{l}\text { Casual full- } \\
\text { time } \\
\text { employees } \\
\text { working } \\
\text { overtime }\end{array}$ \\
\hline 1993 & 39.0 & 15.6 & 23.5 & 40.0 & 28.1 \\
\hline 1995 & 43.0 & 17.2 & 25.9 & 44.1 & 33.0 \\
\hline 1997 & 41.2 & 15.4 & 25.8 & 42.5 & 30.1 \\
\hline 2000 & 40.8 & - & - & 42.5 & 30.7 \\
\hline 2003 & 46.1 & 17.3 & 28.8 & 48.1 & 33.3 \\
\hline
\end{tabular}

Notes: ${ }^{1}$ Includes owner-managers of incorporated enterprises; for every year except 1993 it excludes persons aged 15-19 years who were attending school at the time of the survey.

2 August for 1993, 1995 and 1997; November for 2000 and 2003.

3 "Not paid" comprises all those who stated that their most recent period of overtime was "unpaid overtime", "included in salary package", "time off in lieu”, or "other arrangements".

Source: ABS 2003 and various issues. 
Figure 4.1. Changes in employment rates for working age persons by sex, Australia, 1978-2006 (\%)

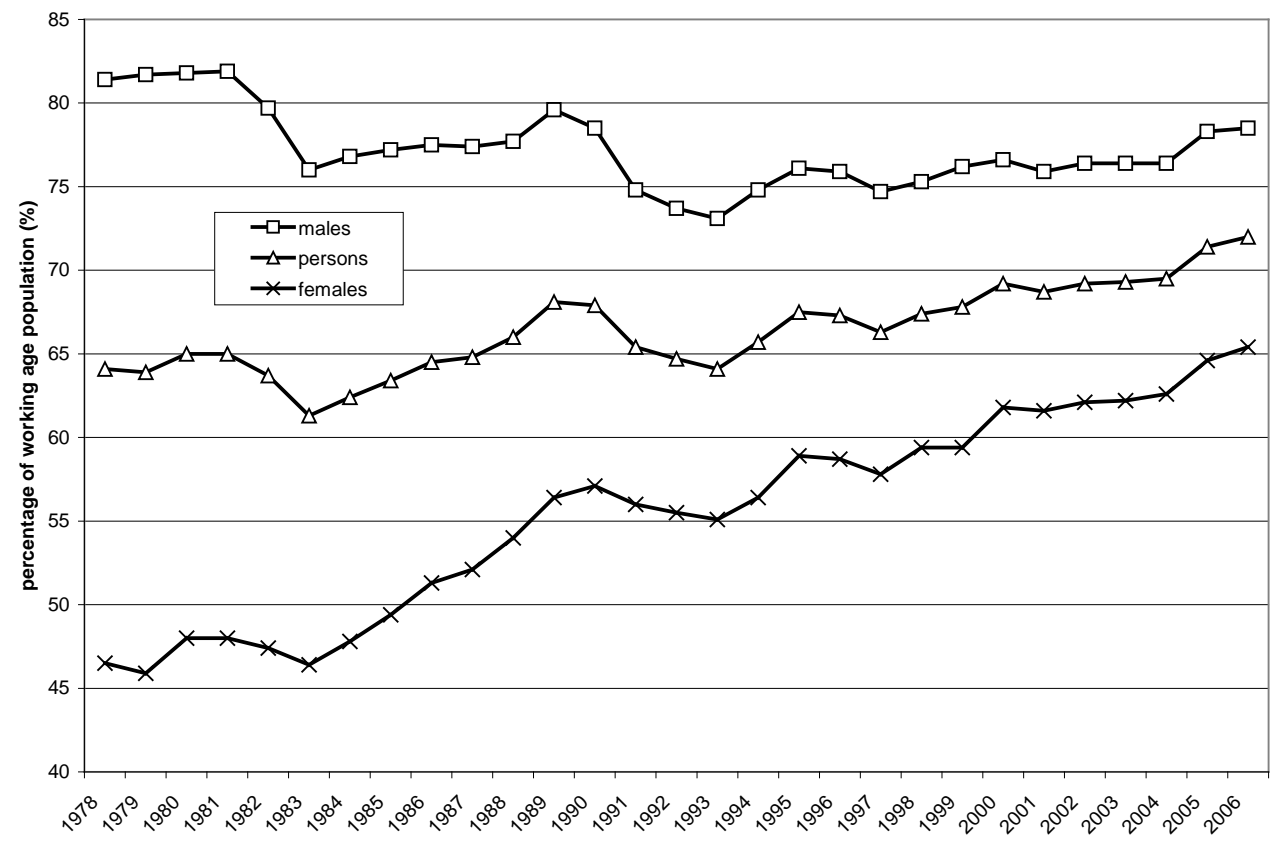

Source: ABS, Labour Force, Australia Data Cubes 6291.0.55.001, Table 01 
Figure 4.2. Unemployed persons and underemployed persons, Australia, 19782006 (\%)

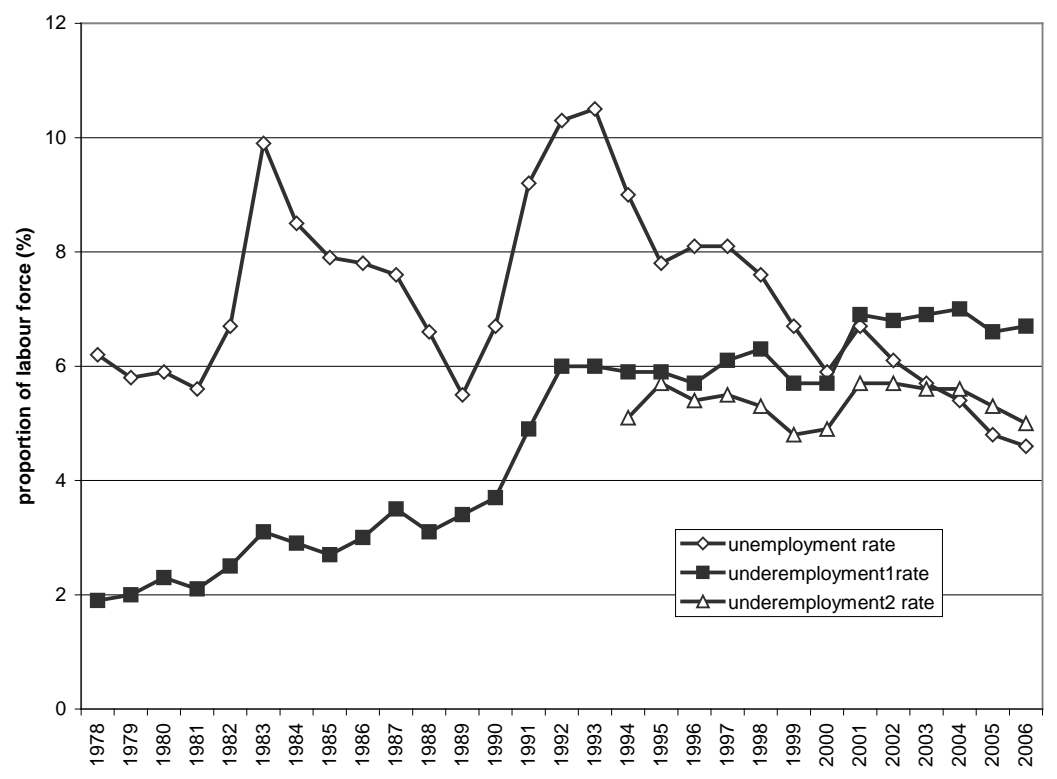

Note: The underemployment1 rate measures part-time workers who prefer to work more hours as a percentage of the labour force.

The underemployment 2 rate is a derivative of the underemployment1 rate, designed to conform more closely to international standards (ABS, 2006e). It starts with part-time workers who want more hours, but it differs in two main respects: first, it includes some full-time workers (those who are usually full time but are working less than 35 hours in the reference week for "economic" reasons); and, second, it does not count all part-time workers who want more hours but only those who were available for more hours (in rough parallel to the measures of unemployment).

Source: ABS Labour Force Australia, Detailed, Quarterly, August 2006, Cat. no. 6291.0.55.003; ABS Underemployed Workers Australia, September 2005, cat. no. 6252.0, cat. no. 6265.0; and ABS Labour Force Australia, Cat. No. 6202.0.55.001. 
Figure 4.3. Employees in full-time “permanent” work, Australia, 1984-2006

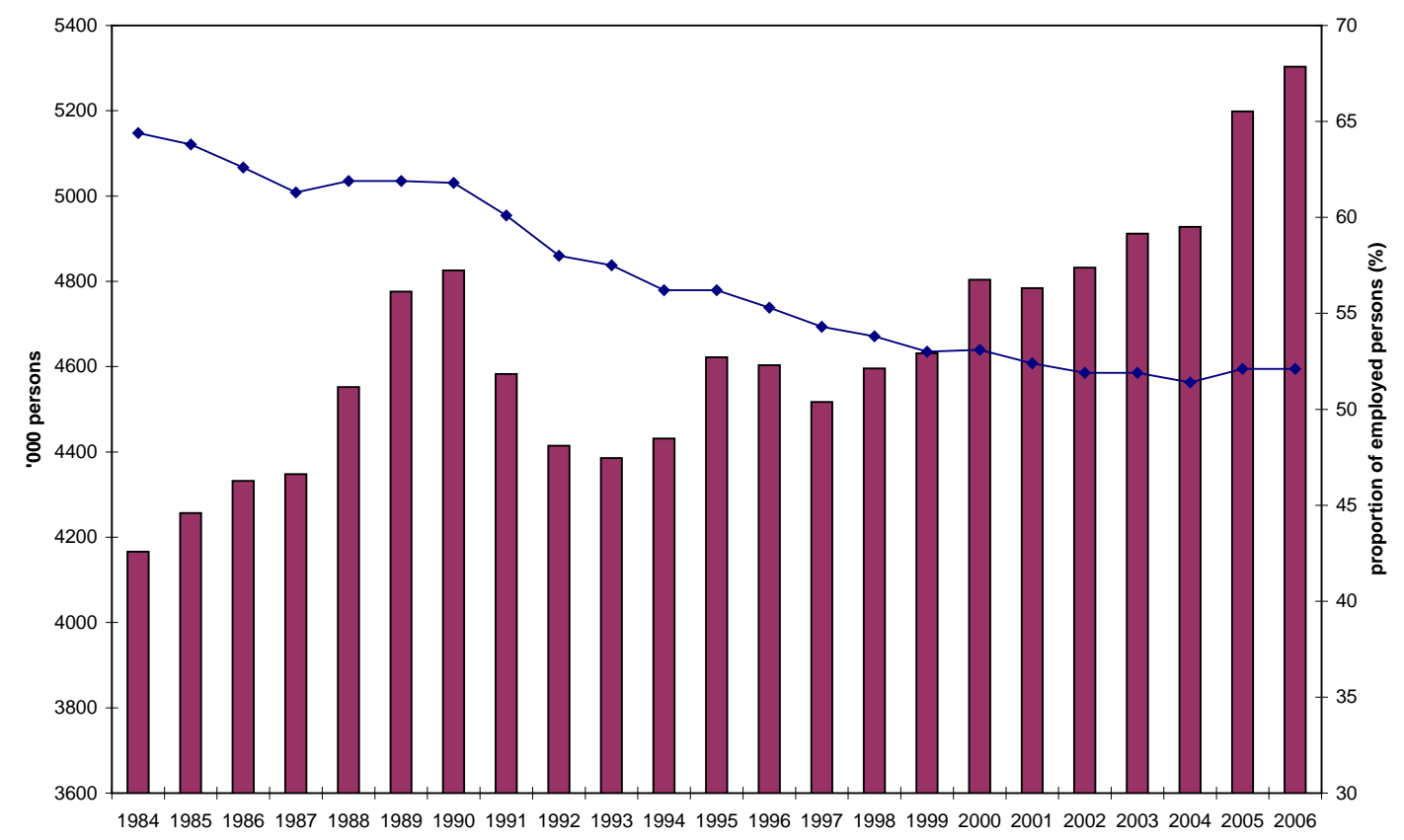

Source: From 1989 data are from ABS Cat. No. 6310.0, varied years; for details on earlier sources see Campbell 2004, p. 88. 
Figure 4.4. Employees in “casual” work, Australia, 1984-2006

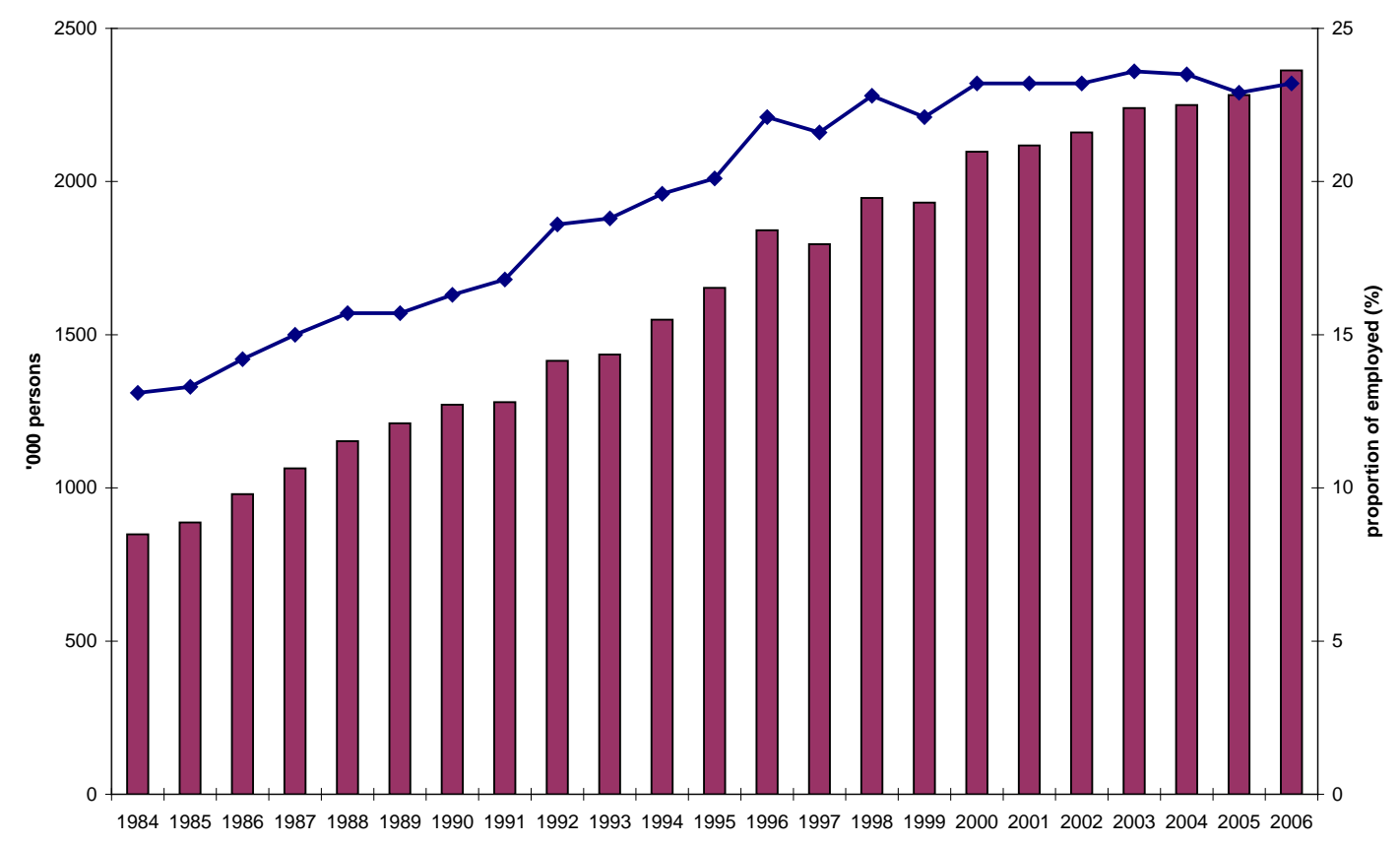

Source: From 1989 data are from ABS Cat. No. 6310.0, varied years; for details on earlier sources see Campbell, 2004, p. 88. 
Figure 4.5. Average actual weekly hours for full-time employees by sex, Australia, 1978-2006

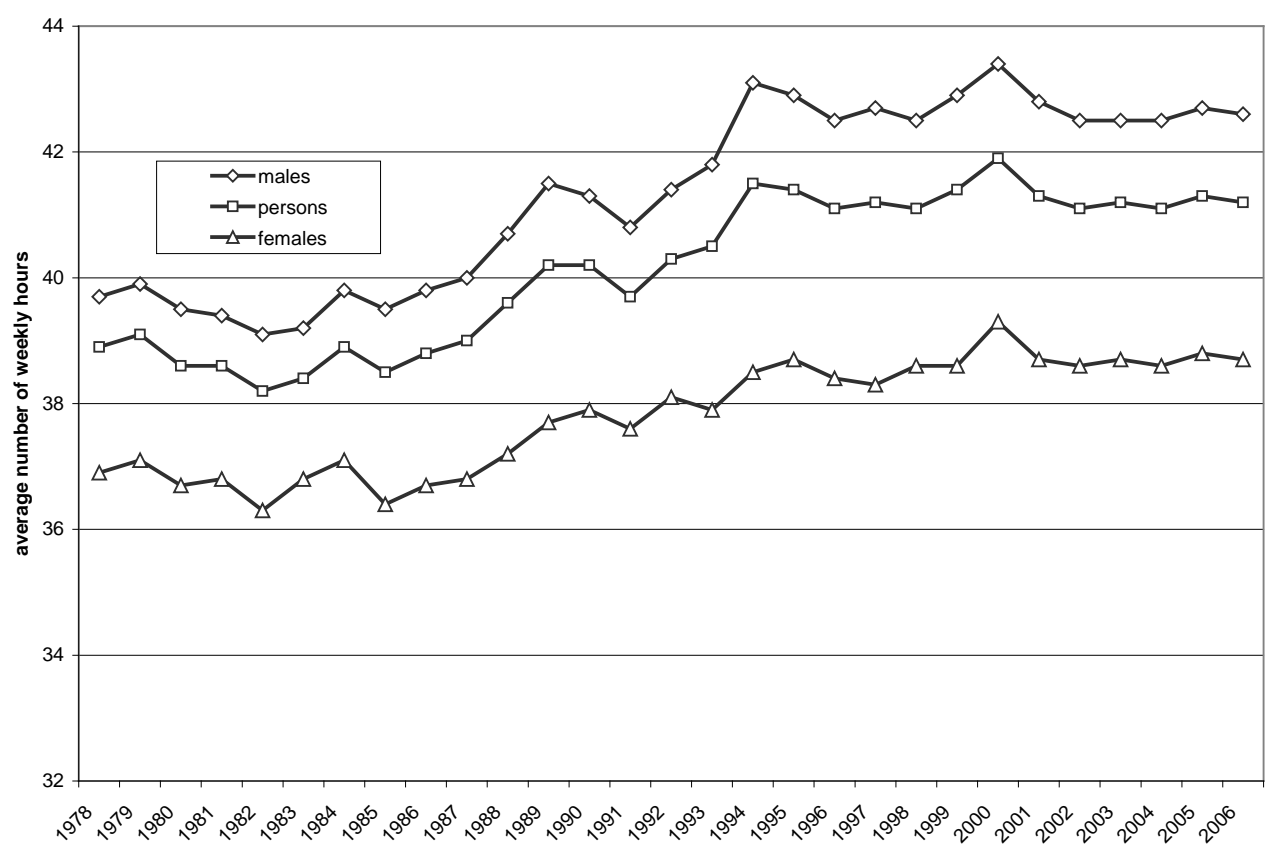

Source: Figures for 1978 to 1984 are from ABS, The Labour Force Australia: Historical Summary 1966 to 1984, cat. no. 6204.0; figures from 1985 are from ABS data cubes, 6291.0.55.03, Labour Force Australia, Table e04. 
Figure 6: Gender pay ratios, based on female/male median weekly earnings for full-time emblovees.

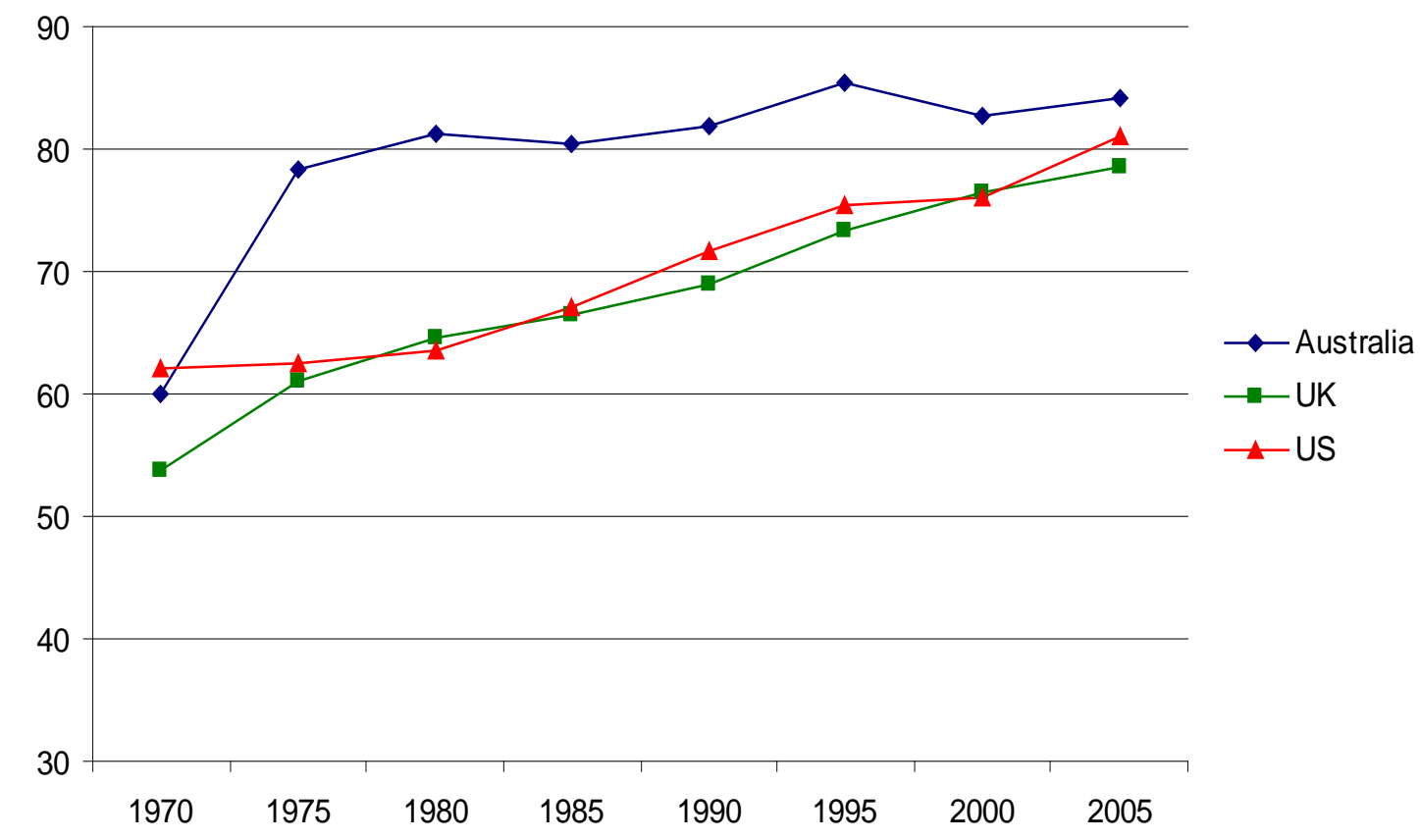

Source: OECD online statistics.

Figure 7: Gender pay equity ratios, total hourly earnings of non-managerial employees and total weekly earnings of full-time adult employees, Australia 19962006

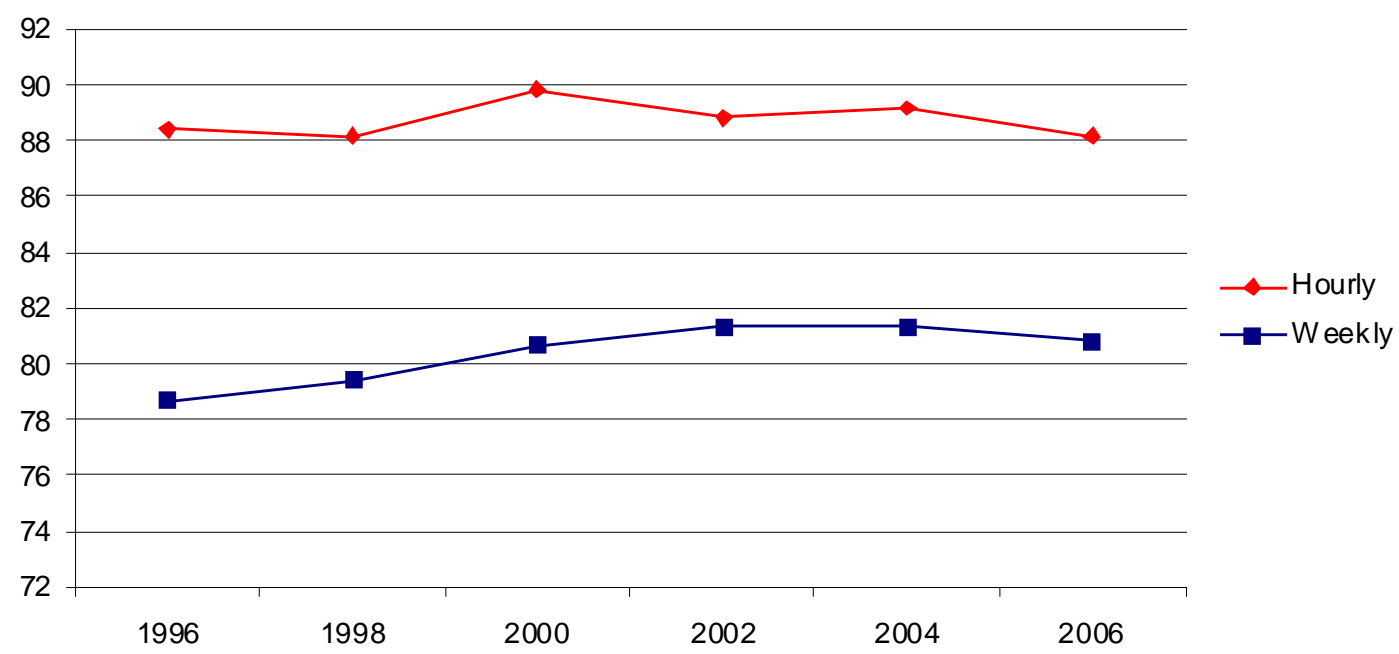

Source of data: ABS 6306.0, 6302.0 

